\title{
SINERGIA
}

REVISTA DO INSTITUTO DE CIÊNCIAS ECONÔMICAS, ADMINISTRATIVAS E CONTÁBEIS (ICEAC)

\section{EFEITO DE CRIAÇÃO OU DESVIO DE COMÉRCIO DAS IMPORTAÇÕES DE PRODUTOS AGROINDUSTRIAIS PELA UNIÃO EUROPEIA: UMA APLICAÇÃO DE INDICADORES ESTATÍSTICOS}

DIOGO DEL FIORI

\begin{abstract}
RESUMO
A União Europeia (UE) coloca em prática grandes níveis de barreiras tarifárias e não tarifárias sobre as importações de produtos agroindustriais em que o bloco europeu detém menor nível de competitividade. No presente trabalho, o período de análise englobou os anos de 1996 a 2013 e, a princípio, o objetivo foi estimar o Índice de Vantagem Comparativa Revelada (IVCR), cujos resultados mostram que o Brasil possui maior nível de competitividade frente aos produtos europeus de carne bovina fresca (SH 0201), carne bovina congelada (SH 0202), carne suína (SH 0203), carne de frango (SH 0207), açúcar bruto (SH 1701) e suco de fruta (SH 2009), que foram os produtos selecionados para a análise por receberem a incidência de pico tarifário. A seguir, empregou-se o Índice de Orientação Regional (IOR), que aponta para uma tendência de exportação fora da UE para carne de frango (SH 0207) e carne suína (SH 0202) e uma diminuição do potencial das exportações do Brasil de carne bovina fresca (SH 0201) e carne bovina congelada (SH 0202). Por fim, o Índice de Introversão ao Comércio e o Índice de Propensão Relativa ao Comércio, desenvolvidos por lapadre (2004), capturaram um maior nível de comércio no âmbito intrabloco em detrimento do comércio extrabloco, sendo de forma mais intensa para a carne bovina fresca, carne bovina congelada, carne suína e carne de frango, de acordo com os resultados do índice de introversão ao comércio e do índice de Propensão Relativa do Comércio Intrarregional, o que mostra a presença do efeito de desvio de comércio das importações desses produtos do bloco europeu com relação aos seus parceiros comerciais. Esse resultado impacta diretamente o Brasil, que ocupa a primeira colocação dentre os 48 principais parceiros comerciais da UE para esses produtos analisados.
\end{abstract}

Palavras-Chave: União Europeia. Produtos agroindustriais. Barreiras tarifárias. Criação de comércio. Desvio de comércio.

\section{ABSTRACT}

The European Union (EU) implements high levels of tariff and non-tariff barriers on imports of agro-industrial products in which the European bloc has the lowest level of competitiveness. In the present study, the period of analysis encompassed the years 1996 to 2013 and, in principle, the objective was to estimate the Revealed Comparative Advantage Index (IVCR), whose results show that Brazil has a higher level of competitiveness against European beef products (HS 0201), frozen beef (SH 0202), pork (SH 0203), chicken meat (SH 0207), raw sugar (SH 1701) and fruit juice (SH 2009), which were the products selected for The analysis for receiving the peak tariff incidence. Next, the Regional Guidance Index (IOR) was used, which points to a trend of exports outside the EU for chicken meat (SH 0207) and pork (SH 0202) and a decrease in Brazil's Fresh beef (SH 0201) and frozen beef (SH 0202). Finally, the Introversion to Trade Index and the Trade-Related Propensity Index developed by lapadre (2004) captured a higher level of intra-bloc trade to the detriment of off-trade, and was more intense for fresh beef , Frozen beef, pork and chicken meat according to the results of the introversion index and the relative intra-regional trade index, which shows the presence of the effect of trade diversion on imports of these products Of the European bloc in relation to its trading partners. This result has a direct impact on Brazil, which is the first of the 48 main EU trading partners for these products.

Key Words: European Union, agro-industrial products, tariff barriers, trade creation, trade diversion

Recebido em: 12-05-2016 Aceito em: 07-02-2017

\section{INTRODUÇÃO}

Pode-se definir a União Europeia (UE) como uma das economias mais robustas do planeta, enfatizando-se o seu alargamento em 2004, com a entrada dos países do leste, o que ocasionou a intensificação das políticas de cunho agrícola por meio da Política Agrícola Comum (PAC), com o objetivo de dar respaldo a esses países do leste europeu.

A PAC teve por meta consolidar um grande mercado para promover a comercialização dos produtos agrícolas e agroindustriais de forma livre, concedendo-se preferência aos produtos europeus. Essa política é caracterizada como discriminatória pelos parceiros comerciais do bloco europeu, haja vista a aplicação de

\footnotetext{
* Doutor em Ciências Econômicas pela Universidade de São Paulo. Mestre em Ciências Econômicas pela Universidade Federal do Rio Grande do Sul (2011)
} 
elevadas barreiras tarifárias, os denominados picos tarifários, sobre as exportações brasileiras de produtos agrícolas e agroindustriais com destino a esse bloco econômico. Isso ocasiona dificuldades de entrada desses produtos no mercado europeu, acarretando queda do nível de competição dos produtos brasileiros, se comparados com os produtos europeus. Caso não ocorressem as políticas de proteção da PAC, o Brasil teria a possibilidade de abastecer o mercado europeu, tendo em vista o menor nível de competitividade da União Europeia frente aos produtores brasileiros de produtos agrícolas e agroindustriais, tornando-a uma grande importadora (FREITAS et al., 2007).

Foi empregado neste artigo índice de introversão ao comércio e índice simétrico de Propensão Relativa do Comércio Intrarregional elaborados por lapadre (2004). Esses índices possuem características próximas aos modelos gravitacionais, pois, dado o nível do PIB e a magnitude do comércio entre dois países, é possível capturar o nível de preferência entre ambos, que é oriunda do compartilhamento de fronteira e língua comum, bem como da concretização de um Acordo Preferencial de Comércio. Logo, esses índices possuem por atribuição mensurar os efeitos de criação e desvio de comércio das importações de produtos agroindustriais selecionados da União Europeia com relação aos seus principais parceiros comerciais. O objetivo deste artigo foi empregar quatro indicadores, sendo que o primeiro deles é o índice de Vantagem Comparativa Revelada (IVCR), para provar que o Brasil detém maior vantagem comparativa com relação à UE nos produtos selecionados, dessa forma, corroborando os resultados do trabalho de Freitas et al. (2007). O segundo é o índice de Orientação Regional (IOR), empregado para averiguar a potencialidade do ingresso das exportações brasileiras no mercado europeu. Os outros dois são os indicadores desenvolvidos por lapadre (2004), respectivamente, o Índice de Introversão ao Comércio, que captura os efeitos de criação ou desvio de comércio intrabloco e também o índice de Propensão Relativa ao Comércio, que mensura os efeitos de criação ou desvio de comércio extrabloco, que é equivalente ao grau de abertura das importações europeias. Os resultados do IOR e dos indicadores de lapadre irá proporcionar uma interpretação mais acurada a respeito do nível de protecionismo comercial exercida pela UE.

A aplicação desses quatro índices foi feita para a carne bovina fresca (SH 0201), carne bovina congelada (SH 0202), carne suína (SH 0203), carne de frango (SH 0207), açúcar bruto (SH 1701) e suco de fruta (SH 2009), que são produtos importados de 48 principais parceiros comerciais, incluindo-se o Brasil e que recebem picos tarifários, sendo que o período definido para a estimação do índice de introversão ao comércio e o índice de Propensão Relativa do Comércio Intrarregional engloba 1996 a 2013, tendo em vista que a elevação do comércio dentro do bloco europeu, fruto das políticas protecionistas com relação aos seus parceiros comerciais não aconteceu somente após o ingresso dos países do leste europeu no ano de 2004, mas já houvera sido constatado em anos anteriores, quando aconteceu o processo de consolidação da Europa no ano de 1995, segundo Freitas et al. (2007).

Este artigo está estruturado em seis seções, sendo esta introdução a primeira delas. A seção 2 apresenta dados empíricos das exportações de produtos agroindustriais selecionados do Brasil para a União Europeia; na sequência, a seção 3 contém a abordagem da metodologia do Índice de Introversão ao Comércio e do índice de Propensão Relativa do Comércio Intrarregional. Na seção 4, há a descrição do cálculo do índice de vantagem comparativa revelada (IVCR), índice de Orientação Regional (IOR) e a aplicação de tarifas média simples pela União Europeia para a exportação dos produtos agroindustriais brasileiros selecionados. A seção 5 contém os resultados e, por fim, as conclusões do artigo estão na seção 6 .

\section{ANÁLISE EMPÍRICA DAS RELAÇÕES COMERCIAIS ENTRE O BRASIL E A UNIÃO EUROPEIA}

De acordo com Freitas et al. (2007), a Política Agrícola Comum (PAC) da União Europeia ocasionou a presença de relações comerciais livres realizadas entre os países pertencentes a esse bloco, resultando em um crescimento de número e variedades de produtos agrícolas ofertados no mercado europeu. Isso ocasionou impactos negativos nas exportações dos países não pertencentes a esse bloco, como o Brasil. Importante destacar que as ações objetivando impulsionar a produção interna por intermédio da PAC transformaram a UE em um exportador líquido de produtos agrícolas processados ou agrícolas (FREITAS, 2007), sendo que esse fato não ficou restrito somente no período que sucedeu a entrada dos países do Leste Europeu, que ocorreu em 2004, mas já estava presente quando a UE-15 estava se consolidando no ano de 1995. O aparecimento da PAC no âmbito da União Europeia possibilitou um crescimento de itens e do número de variedades concedidos por cada país pertencente a este bloco econômico, dificultando o acesso pelos países não membros ao mercado europeu. A elevação dessa diversificação é resultado da especificação de cada um dos países membros com relação à produção de produtos agrícolas. Freitas (2004) realizou a localização de cada um dos produtos agroindustriais dentro da União Europeia, constatando que a produção de vegetais e frutas encontram-se no mediterrâneo e a produção de lácteos, carnes, oleaginosas e cereais é feita em todos os países da União Europeia.

Esse bloco, por estar na condição de união econômica, automaticamente detém todas as 
características de uma união aduaneira ${ }^{1}$, sendo que um desses atributos é o uso de uma Tarifa Externa Comum (TEC) sobre as importações dos seus parceiros comerciais, tornando-os menos competitivos se comparados aos países pertencentes à União Europeia.

Freitas et al. (2007) desenvolveu trabalho com o intuito de identificar produtos agroindustriais cobertos por tarifas colocadas em prática pela União Europeia. As exportações de produtos agrícolas do Brasil para o mercado europeu recebem a incidência de tarifas específicas, por possuírem um patamar de competitividade mais alto, ocasionando um nível de proteção mais elevado, pois, quando há diminuição do preço, existe elevação da proteção. As conclusões obtidas por Freitas et al. (2007) mostram que os produtos que recebem proteção são os segmentos de carnes e açúcar.

Os produtos agroindustriais ${ }^{2}$ exportados pelo Brasil para a União Europeia são o complexo soja (grão, farelo e óleo), açúcar (bruto), café (em grão e solúvel), suco de laranja concentrado, carnes (frango, suína e bovina) e fumo. Esses produtos possuem grande participação com relação ao valor total dos produtos agroindustriais exportados, conforme a Tabela 1, no período compreendido entre 2003 a 2012.

TABELA 1 - Participação percentual do complexo soja (grão, farelo e óleo), açúcar (bruto), café (em grão e solúvel), suco de laranja concentrado, carnes (frango, suína e bovina) e fumo com relação ao valor total exportado de produtos agroindustriais

\begin{tabular}{cc}
\hline Ano & Percentagem (\%) \\
\hline 2003 & $82 \%$ \\
\hline 2004 & $82 \%$ \\
\hline 2005 & $83 \%$ \\
\hline 2006 & $80 \%$ \\
\hline 2007 & $72 \%$ \\
\hline 2008 & $74 \%$ \\
\hline 2009 & $77 \%$ \\
\hline 2010 & $74 \%$ \\
\hline 2011 & $58 \%$ \\
\hline 2012 & $76 \%$ \\
\hline
\end{tabular}

FONTE: UN Comtrade (Tabulado pelo autor)

Na Figura 1, observa-se que, no período entre os anos de 1996 a 2013, as exportações do café (em grão e solúvel) apresentaram, a princípio, um ligeiro crescimento entre os anos de 1996 e 1997, seguindose de uma diminuição até 2003 e crescimento de 2003 até 2011, sendo que o ano de 2011 é caracterizado pelo maior valor das exportações dentro da série analisada, e queda dessas exportações de 2011 até o ano de 2013. As exportações da soja elevaram-se de 1996 até 1997, com diminuição até 1999 e aumento desse ano até 2008. Ainda no que se refere à soja (grão, farelo e óleo), houve queda das exportações entre os anos de 2008 a 2010 e um aumento entre os anos de 2010 a 2012 e queda em 2013.

\footnotetext{
${ }^{1}$ Os níveis de integração regional se dividem em cinco estágios: Área de livre comércio: Remoção Interna de tarifa e quota; União Aduaneira - Remoção interna de tarifa e quota e a existência de uma Tarifa Externa Comum (TEC); Mercado Comum- livre circulação de fatores de produção, bens e serviços; União Econômica- Harmonização ou coordenação de algumas políticas nacionais e a transferência de algumas políticas para um nível supranacional e; Intergração Econômica Total-Adoção de moeda única e sistema econômico comum com um banco central único.

${ }^{2}$ 01) Animais vivos; 02) Carnes e miudezas, comestíveis, 03) Peixes e crustáceos, moluscos e outros invertebrados aquáticos; 04) Leite e laticínios; Ovos de aves; Mel natural, Produtos de origem animal, não especificados nem compreendidos; 05) Outros produtos de origem animal, não especificados nem compreendidos em outros capítulos; 06) Plantas vivas e produtos de floricultura; 07) Produtos hortícolas, plantas, raízes e tubérculos, comestíveis; 08) Frutas, cascas, de cítricos e de melões; 09) Café, chá, mate e especiarias; 10) Cereais; 11) Produtos da indústria de moagem; malte, amidos e féculas, inulina, glúten de trigo; 12) Sementes e frutos oleaginosos, grãos, sementes e frutos diversos, plantas industriais ou medicinais, palhas e forragens; 13) Gomas, resinas e outros sucos e extratos vegetais; 14) Matérias para entrançar outros produtos de origem vegetal, não especificados nem compreendidos em outros capítulos; 15) Gorduras e óleos animais ou vegetais, Produtos da sua dissociação, Gorduras alimentares elaboradas, Ceras de origem animal ou vegetal, 16) Preparações de carne, de peixes ou de crustáceos, de moluscos ou de outros invertebrados aquáticos; 17)Açúcares e produtos de confeitaria; 18) Cacau e suas preparações; 19) Preparações à base de cereais, farinhas, amidos, féculas ou de leite, Produtos de pastelaria; 20) Preparações de produtos hortícolas, de frutas ou de outras partes de plantas; 21) Preparações alimentícias diversas; 22) Bebidas, líquidos alcoólicos e vinagres; 23) Resíduos e desperdícios das indústrias alimentares, alimentos preparados para animais; 24) Fumo (tabaco) e seus sucedâneos manufaturados (MDIC).
} 


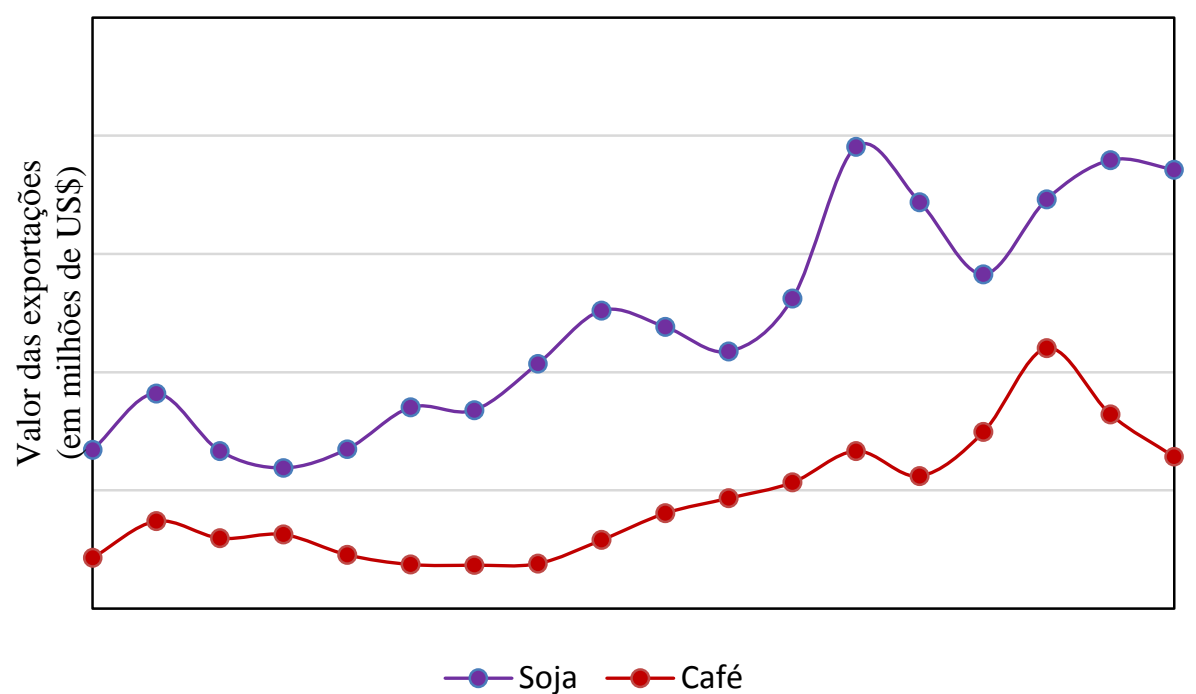

FIGURA 1-Valor das exportações agroindustriais de Soja (grão, farelo e óleo) e Café (em grão e solúvel) do Brasil para a União Europeia (MILHÕES DE US\$) no período entre os anos 1996 a 2013.

FONTE:UN COMTRADE (tabulado pelo autor).

Com relação às informações da Figura 2, nota-se que a carne bovina possui um patamar superior de exportações com relação ao fumo no período entre os anos de 2003 a 2006, sendo que entre os anos de 1996 a 1999, as exportações do fumo foram superiores às exportações da carne bovina; a partir do ano de 2000, ocorreu elevação dessas exportações até o ano de 2009, que é o pico (ponto mais elevado das exportações) da série, com ligeira queda e estabilização até o ano de 2013. A partir do ano de 2007, as exportações de carne bovina sofrem uma grande queda, atingindo um patamar mínimo no ano de 2008 , com crescimento até o ano de 2009 e diminuição e estabilização até o ano de 2013.

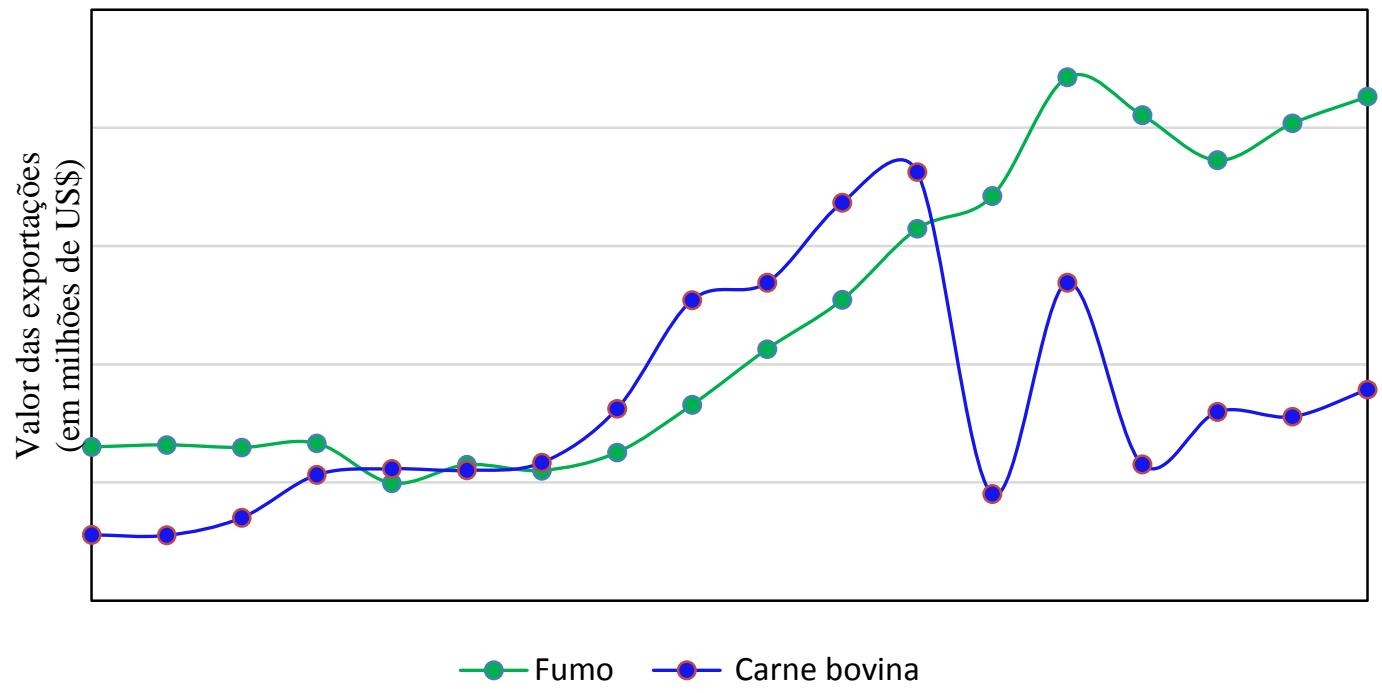

FIGURA 2 -Valor das exportações de Fumo e Carne Bovina do Brasil para a União Europeia (MILHÕES DE US\$) no período entre os anos 1996 a 2013.

FONTE:UN COMTRADE (tabulado pelo autor).

Com base nas informações da Figura 3, nota-se claramente que a carne suína possui baixos patamares de exportação no período compreendido entre os anos de 1996 a 2013, quando comparada aos demais produtos que constam nessa figura, como o suco de fruta, carne de frango e o açúcar bruto. É importante destacar que a exportação do açúcar bruto se apresenta em baixos patamares entre os anos de 1996 a 2006, com um impulso de 2007 até 2011 e diminuição até 2013. As exportações de carne de frango se apresentaram em um patamar constante entre 1996 e 1999, com aumento a partir de 1999, com um pico (nível máximo exportado) em 2007 e diminuição de 2007 até 2013. O patamar da exportação para o suco de fruta é o mais elevado entre os quatro produtos da série. A trajetória desse produto oscila positivamente 
e negativamente entre 1996 e 2013, com os valores mais elevados nos anos 2011, 2012 e 2013 e valor mais baixo em 1997 e 1998.

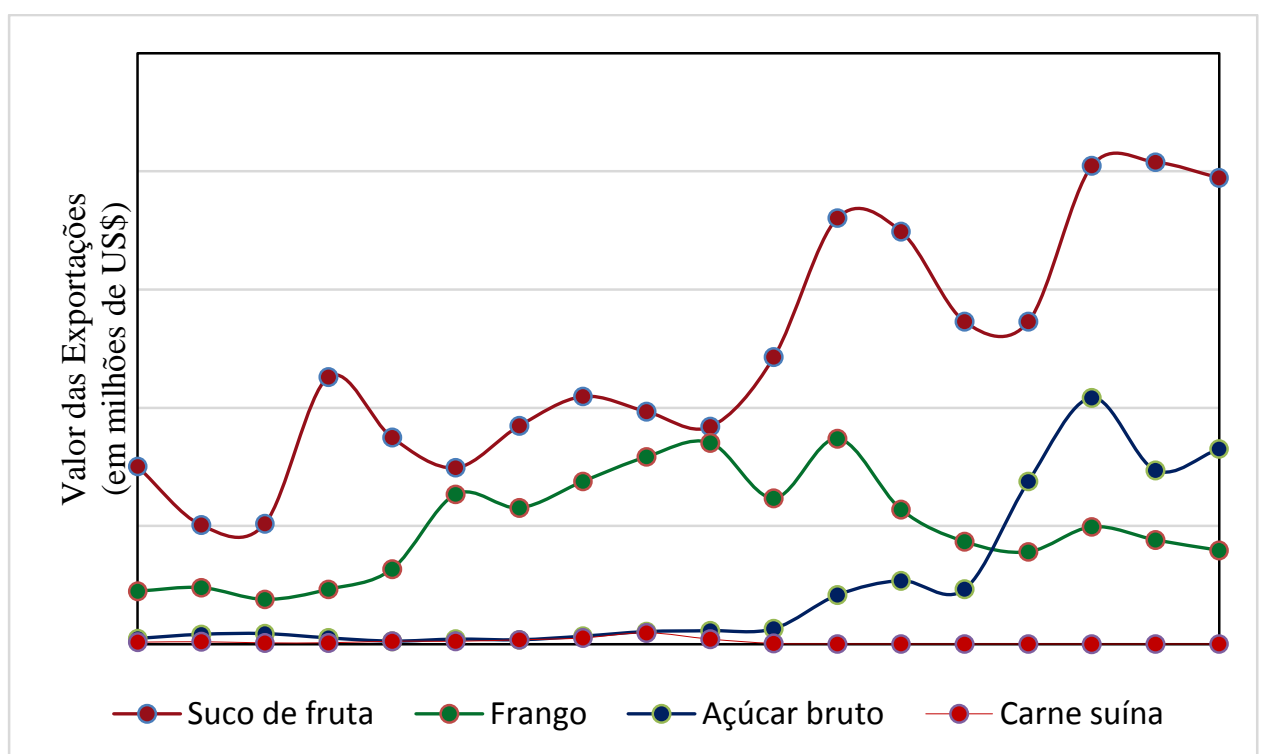

FIGURA 3 - Exportações de Suco de Fruta, Carne de Frango, Açúcar Bruto e Carne Suína do Brasil para a União Europeia (MILHÕES DE US\$) entre os anos de 1996 a 2013.

FONTE:UN COMTRADE (tabulado pelo autor).

\section{CRIAÇÃO E DESVIO DE COMÉRCIO: UMA APLICAÇÃO DOS INDICADORES DE IAPADRE}

$\mathrm{Na}$ economia, o bem estar é mensurado de duas maneiras: observação ex-post, com o objetivo de se averiguar a magnitude do desvio ou da criação de comércio. Para tal, mensuram-se equações relacionadas ao modelo gravitacional, em que o fluxo das relações comerciais ocorre tendo por base a renda e o tamanho da população de países que fazem parte de um mesmo arranjo regional e também com observação ex-ante, empregando-se os modelos de equilíbrio parcial e geral. Assim sendo, definem-se modelos de equilíbrio geral e parcial como aqueles que possuem formas específicas e funcionais, com parâmetros que representam variáveis econômicas em anos que antecedem a formação do bloco econômico, como as tarifas sobre importações e, então, calculam-se os efeitos dessas tarifas sobre o bemestar.

Esses estudos que usam modelos de equilíbrio parcial e geral e os modelos econométricos são incompletos, de acordo com Panagaryia (2000), que ressalta como conflitantes os seus resultados no que se referem aos impactos provenientes dos Acordos de Integração Regional sobre as relações comerciais e bem-estar. Segundo Adams et al. (2003), há muita controvérsia nos métodos econométricos, tendo em vista que as estimativas são muito distintas nas diferentes análises.

Baldwin et al. (1995) também destacam a não consistência dos resultados oriundos dos modelos econométricos e de equilíbrio geral, pois, grande parte dos resultados desses modelos não tinham preocupações com relação aos impactos sobre o bem-estar, sendo que só em especiais ocasiões é que os efeitos do volume de comércio proporcionam medidas exatas sobre o bem-estar oriundos de um Acordo de Integração Regional.

Estudar as relações do passado no que diz respeito ao comércio de países ou blocos econômicos parece ser mais factível, com relação aos modelos de equilíbrio parcial e geral, para realizar a previsão do futuro. Entretanto, o uso de inúmeras variáveis para captar o impacto do processo da formação de um acordo comercial sobre o bem-estar pode tornar restritivo o estudo, tendo em vista que esses modelos simplificam demasiadamente o mundo real.

Assim, o uso dos Indicadores de Integração Regional possui por atributo estudar o desempenho dos países que fazem parte dos acordos regionais de maneira individual, bem como a evolução econômica dos mesmos. Logo, tais indicadores possuem a propriedade de mensurar a evolução do processo integracionista no decorrer do tempo com relação aos países membros.

Os índices de intensidade comercial estão alicerçados em uma base comparativa entre o possível e o atual valor do fluxo bilateral de comércio em um contexto de "neutralidade geográfica", que é uma situação em que cada país possui a mesma importância com relação ao comércio mundial (KUNIMOTO, 1977), ou seja, a distribuição geográfica do comércio regional pode ser considerada neutra na ocasião em que o peso do bloco econômico no comércio de cada um dos países membros do mesmo é igual ao peso do comércio 
desses países no mercado mundial, caracterizando-se como uma situação de ausência de direção preferencial do comércio.

Dado o volume das relações comerciais entre dois países e a magnitude do PIB de ambos, o índice de intensidade do comércio bilateral tem por meta exercer a captura do grau de preferências recíprocas entre dois países que são parceiros comerciais, que recebem influência das políticas de integração, língua comum, mesma fronteira, dentre outros fatores de aproximação.

Há vantagens para o uso de índices de mensuração, como a comparação de diferentes grupos sociais e áreas geográficas, pois, tais índices possuem importância estatística, custos reduzidos e fácil compreensão (ANDERSON, 1991).

lapadre (2004) descreve indicadores com o fito de medir a intensidade relativa do comércio intrarregional com relação ao comércio da região (União Europeia) com o resto do mundo. A introversão ao comércio pode ser resultado de inúmeros fatores, incluindo o efeito de desvio de comércio dos acordos de integração regional. Entretanto, uma elevação do índice de introversão ao comércio pode também refletir um processo de criação de comércio sem efeito de desvio de comércio com o resto do mundo. Introversão ao Comércio significa que o peso da região no seu próprio comércio é maior do que o peso do comércio da região com relação ao resto do mundo.

Dessa forma, lapadre (2004) apresenta o índice simétrico de propensão relativa ao comércio intraregional $\left(S P J_{i}\right)\left(S P J_{i}\right)$, que mensura, de forma simultânea, os fluxos de comércio intrarregional e o grau de abertura relativa da União Europeia, que equivale ao efeito de criação ou desvio de comércio das importações desse bloco econômico, ou seja, o comércio total da União Europeia é composto pela soma das relações comerciais intrabloco e extrabloco. Logo, uma elevação do comércio intrabloco ocasiona uma queda no comércio extrabloco, o que denota uma queda do grau de abertura relativa, acarretando efeito de desvio de comércio das importações do bloco europeu.

Calcular-se-á esses índices para a União Europeia com relação ao mundo, incluindo-se o Brasil, que, de acordo com a tabela 2, ocupa a primeira colocação dentre os 48 principais parceiros comerciais da União Europeia no que tange às importações dos produtos de interesse selecionados. A intensidade do comércio intrarregional da região i $\left({ }^{I_{i}} I_{i}\right)$ pode ser medida pelo índice de introversão do comércio $S J_{i}$ representado pela equação 1 .

$$
\begin{aligned}
& S J_{i}=\frac{\left(H J_{i}-1\right)}{\left(H J_{i}+1\right)} \\
& H J_{i} H J_{i}=\frac{H I_{i}}{H E_{i}} \frac{H I_{i}}{H E_{i}} \\
& H I_{i}=\frac{S_{i}}{V_{i}}=\frac{\frac{t_{i i}}{t_{i}}}{\frac{t_{r i}}{t_{r}}}
\end{aligned}
$$

sendo que tri é o comércio extrarregional da região $i$ e tr é o comércio total do resto do mundo, $\mathrm{t}_{\mathrm{ii}}$ é o comércio total intrabloco da região e ti é o comércio total da região (União Europeia).

$$
H E_{i}=\left(1-\frac{t_{i i}}{t_{i}}\right) /\left(1-\frac{t_{r i}}{t_{r}}\right)
$$

O índice ${ }^{H} J_{i} H J_{i}$ varia de zero (sem comércio intrarregional) ao infinito (sem comércio extrarregional). Isso faz com que ${ }^{S J_{i} S J_{i}}$ varie de menos um a mais um, em que o valor de menos um denota ausência de comércio intrarregional e o valor de mais um significa ausência de comércio extrarregional.

O índice de propensão relativa ao comércio intrarregional $\left(S P J_{i}\right)\left(S P J_{i}\right)$ é representado por intermédio da equação 7 .

$$
\begin{aligned}
& S P J_{i}=\left(P J_{i}-1\right)\left(P J_{i}+1\right) \\
& P J_{i}=\frac{P I_{i}}{P E_{i}}=\frac{\left(\frac{S_{i}}{G_{i}}\right)}{\left[\left(\frac{1-S_{i}}{1-G_{i}}\right)\right]} \\
& S_{i}=\frac{t_{i i}}{t_{i}} \text { e } G_{i}=\frac{y_{i}}{Y}
\end{aligned}
$$


$S P J S P J$ varia de menos um a mais um, sendo que o valor zero denota uma distribuição neutra do comércio intrabloco e extrabloco, o menos um denota ausência de comércio intrarregional e mais um ausência de comércio extrarregional.

TABELA 2 - Relação dos países considerados para a amostra selecionada, apresentada com os respectivos códigos da Nação Unida, código da ISO referentes à importação dos produtos selecionados Carne Bovina Fresca (SH 0201), Carne Bovina Congelada (SH 0202), Carne Suína (SH 0203), Carne de Frango (SH 0207), Açúcar Bruto (SH 2009) e Suco de Fruta (1701) pela União Europeia e a participação percentual das importações oriundas de cada um desses países com relação ao total importado pela UE no que se refere a esses produtos selecionados para o período que engloba os anos de 1996 a 2013.

\begin{tabular}{|c|c|c|c|}
\hline País & Código ISO & Código UN & $\begin{array}{l}\text { Percentual com } \\
\text { relação ao total } \\
\text { importado (\%) }\end{array}$ \\
\hline Algeria & DZA & 12 & 0.34 \\
\hline Argentina & ARG & 32 & 10.66 \\
\hline Australia & AUS & 36 & 1.81 \\
\hline Barbados & BRB & 52 & 0.49 \\
\hline Belize & $\mathrm{BLZ}$ & 84 & 1.01 \\
\hline Botswana & BWA & 72 & 0.72 \\
\hline Brazil & BRA & 76 & 40.88 \\
\hline Costa do Marfim & CIV & 384 & 0.18 \\
\hline Canada & CAN & 124 & 0.40 \\
\hline Chile & $\mathrm{CHL}$ & 152 & 2.08 \\
\hline China & $\mathrm{CHN}$ & 156 & 2.29 \\
\hline Congo & COG & 178 & 0.08 \\
\hline Costa Rica & $\mathrm{CRI}$ & 188 & 0.79 \\
\hline Cuba & CUB & 192 & 1.12 \\
\hline República Dominicana & DOM & 214 & 0.15 \\
\hline Equador & ECU & 218 & 0.47 \\
\hline Fiji & FJI & 242 & 2.56 \\
\hline Honduras & HND & 340 & 0.04 \\
\hline India & IND & 356 & 0.35 \\
\hline Indonésia & IDN & 360 & 0.20 \\
\hline Israel & ISR & 376 & 1.69 \\
\hline Jamaica & JAM & 388 & 1.91 \\
\hline Quênia & KEN & 404 & 0.25 \\
\hline Laos & LAO & 418 & 0.22 \\
\hline Madagáscar & MDG & 450 & 0.26 \\
\hline Malawi & MWI & 454 & 0.88 \\
\hline Mauritânia & MRT & 478 & 0.00 \\
\hline República de Maurício & MUS & 480 & 7.63 \\
\hline México & MEX & 484 & 0.37 \\
\hline Moldávia & MDA & 498 & 0.65 \\
\hline Moçambique & $\mathrm{MOZ}$ & 508 & 1.11 \\
\hline Namíbia & NAM & 516 & 0.86 \\
\hline Nova Zelândia & NZL & 554 & 1.16 \\
\hline Noruega & NOR & 578 & 0.14 \\
\hline Paraguai & PRY & 600 & 0.31 \\
\hline África do Sul & ZAF & 710 & 0.36 \\
\hline Sudão & SDN & 736 & 0.16 \\
\hline
\end{tabular}


Continuação

\begin{tabular}{cccc}
\hline País & Código ISO & Código UN & $\begin{array}{c}\text { Percentual com } \\
\text { relação ao total } \\
\text { importado (\%) }\end{array}$ \\
\hline Suazilândia & SWZ & 748 & 2.57 \\
\hline Suíça & CHE & 756 & 1.15 \\
\hline Tanzânia & TZA & 834 & 0.25 \\
\hline Tailândia & THA & 764 & 1.12 \\
\hline Trindade e Tobago & TTO & 780 & 0.37 \\
\hline Turquia & TUR & 792 & 0.33 \\
\hline $\begin{array}{c}\text { Emirados Árabes } \\
\text { Unidos }\end{array}$ & ARE & 784 & 0.22 \\
\hline Estados Unidos & USA & 840 & 2.40 \\
\hline Uruguai & URY & 858 & 4.72 \\
\hline Zâmbia & ZMB & 894 & 0.81 \\
\hline Zimbábue & ZWE & 716 & 1.48
\end{tabular}

FONTE: UN COMTRADE

\section{APLICAÇÃO DE BARREIRAS TARIFÁRIAS E NÃO TARIFÁRIAS SOBRE AS IMPORTAÇÕES DE PRODUTOS AGROINDUSTRIAIS DO BRASIL}

Estudo da Confederação Nacional da Agricultura (CNA) no ano de 2014 mostra que os picos tarifários ${ }^{3}$ são importantes barreiras à importação de alguns produtos agrícolas brasileiros pela UE, o que acaba impactando negativamente o fluxo de comércio no âmbito internacional. A tabela 3 contém informações sobre as tarifas empregadas pela União Europeia sobre as importações do Brasil de Açúcar Bruto (SH 1701), Carne de Frango (SH 0207), Carne Suína (SH 0203), Carne Bovina Fresca (SH 0201), Carne Bovina Congelada (SH 0202), Suco de fruta (SH 2009), para o período que engloba os anos de 1996 a 2013.

Assim, os produtos selecionados para o cálculo dos indicadores de lapadre (2004) são aqueles que recebem a incidência de picos tarifários ao longo de todo o período entre os anos de 1996 a 2013, ou seja, os produtos que recebem a incidência de tarifas maiores ou iguais a $20 \%$ de 1996 até 2013 , como o açúcar bruto (SH 1701), carne de frango (SH 0207), Carne Suína (SH 0203), carne bovina fresca (SH 0201), carne bovina congelada (SH 0202) e suco de fruta (SH 2009), conforme a tabela 2.

TABELA 3 - Tarifa Média Simples da União Europeia sobre o Brasil com relação ao Açúcar Bruto (SH 1701), Carne de Frango (SH 0207), Carne Suína (SH 0203), Carne Bovina Fresca (SH 0201), Carne Bovina Congelada (SH 0202), Fumo (2401), Suco de fruta (SH 2009), Soja Grãos (SH 1201), Soja Farelos (SH 2304), óleo de Soja (SH 1507), Café Grãos (SH 0901), Café Solúvel (SH 2101) para o período que engloba os anos de 1996 a 2013.

\begin{tabular}{|c|c|c|c|c|c|c|}
\hline Ano & $\begin{array}{c}\text { Carne de } \\
\text { frango }\end{array}$ & Carne Suína & $\begin{array}{c}\text { Carne Bovina } \\
\text { fresca }\end{array}$ & $\begin{array}{c}\text { Carne Bovina } \\
\text { Congelada }\end{array}$ & Suco de fruta & Açúcar Bruto \\
\hline 1996 & $36.52 \%$ & $45.29 \%$ & $93.21 \%$ & $164.93 \%$ & $38.36 \%$ & $74.67 \%$ \\
\hline 1997 & $35.64 \%$ & & $118.11 \%$ & $168.96 \%$ & $41.44 \%$ & $74.14 \%$ \\
\hline 1998 & $35.21 \%$ & & $103.24 \%$ & $146.18 \%$ & $38.30 \%$ & $85.85 \%$ \\
\hline 1999 & $33.79 \%$ & $36.38 \%$ & $103.12 \%$ & $145.79 \%$ & $34.71 \%$ & $69.59 \%$ \\
\hline 2000 & $26.67 \%$ & $30.03 \%$ & $90.25 \%$ & $124.34 \%$ & $31.70 \%$ & $65.10 \%$ \\
\hline 2001 & $28.43 \%$ & $29.39 \%$ & $87.85 \%$ & $111.71 \%$ & $33.12 \%$ & $65.76 \%$ \\
\hline 2002 & $28.00 \%$ & $24.30 \%$ & $82.48 \%$ & $118.14 \%$ & $25.70 \%$ & $65.76 \%$ \\
\hline 2003 & $29.98 \%$ & $28.72 \%$ & $76.63 \%$ & $115.64 \%$ & $25.87 \%$ & $68.88 \%$ \\
\hline 2004 & $31.16 \%$ & $30.72 \%$ & $77.07 \%$ & $118.59 \%$ & $28.54 \%$ & $98.85 \%$ \\
\hline 2005 & $32.80 \%$ & $31.18 \%$ & $85.85 \%$ & $120.29 \%$ & $26.65 \%$ & $75.75 \%$ \\
\hline 2006 & $30.30 \%$ & $27.44 \%$ & $71.62 \%$ & $126.67 \%$ & $28.93 \%$ & $73.34 \%$ \\
\hline 2007 & $29.37 \%$ & $28.20 \%$ & $80.43 \%$ & $106.58 \%$ & $27.18 \%$ & $69.41 \%$ \\
\hline 2008 & $28.74 \%$ & $23.98 \%$ & $74.20 \%$ & $115.61 \%$ & $25.47 \%$ & $70.72 \%$ \\
\hline 2009 & $29.40 \%$ & & $74.66 \%$ & $111.66 \%$ & $27.33 \%$ & $66.50 \%$ \\
\hline 2010 & $27.47 \%$ & & $72.44 \%$ & $103.85 \%$ & $25.72 \%$ & $66.68 \%$ \\
\hline 2011 & $25.14 \%$ & & $66.84 \%$ & $97.39 \%$ & $27.50 \%$ & $57.84 \%$ \\
\hline 2012 & $20.98 \%$ & & $57.27 \%$ & $80.15 \%$ & $25.37 \%$ & $59.52 \%$ \\
\hline 2013 & $39.42 \%$ & $29.59 \%$ & $57.11 \%$ & $229.25 \%$ & $28.09 \%$ & $64.36 \%$ \\
\hline
\end{tabular}

FONTE: WITS

\footnotetext{
${ }^{3}$ Não há uma definição padrão para picos tarifários. A OMC define picos tarifários para tarifas de $15 \%$ ou mais para produtos industriais, sem definição para produtos agrícolas. Para a Food and Agriculture Organization of the United Nations (FAO), a definição pico tarifário são tarifas com patamares de $20 \%$ ou mais.
} 
Para confirmar a afirmativa de Freitas et al. (2007) acerca da vantagem comparativa dos produtos agroindustriais do Brasil frente aos produtos agroindustriais europeu, utiliza-se o índice de Vantagem Comparativa Revelada (IVCR) de Balassa (1965). Existe propriedade atrelada a esse índice no tocante à mensuração de vantagens comparativas do Brasil com relação à União Europeia no que diz respeito aos produtos selecionados. A obtenção do valor deste índice é feita por meio da divisão da fração da exportação do produto $j$ (Açúcar Bruto, Suco de Fruta, Carne de Frango, Carne Suína, Carne Bovina Congelada, Carne Bovina Fresca) com relação à totalidade das exportações do país $i$ com relação ao Brasil e à participação das exportações do mesmo produto j pela região $k$, que é a União Europeia, com relação à exportação total deste bloco.

A definição do índice está representada pela equação 10:

$$
C_{j}=X_{i j} / X_{i} / X_{k j} / X_{k}
$$

O valor total das exportações da região $k$ é representado pela variável $X_{k,, 0}$ valor das exportações do produto $j$ realizada pela região $k$ é representada pela variável $X_{k j}$, a variável $X_{i}$ é o valor total das exportações do país $i$ e o valor das exportações do produto j pelo país i é representada pela variável $X_{i j}$.

A variação do índice $C_{j}$ está entre zero e infinito. Se o valor desse índice estiver acima da unidade, o país $i$ possui vantagem comparativa revelada com relação à exportação do produto $j$. Entretanto, no caso em que exista valor abaixo de um para este índice, existe desvantagem comparativa revelada para o país $j$.

Existe vantagem comparativa para o período que engloba os anos 1996 a 2013, em virtude do valor do índice $C_{j}$ acima de um para a produção brasileira de Açúcar Bruto (SH 2009), Suco de Fruta (SH 1701), carne de Frango (SH 0207), carne Suína (SH 0203), carne Bovina Congelada (SH 0202) e Carne Bovina Fresca (SH 0201), exceto, para o ano de 1999, no que diz respeito à carne Suína (SH 0203) e para os anos de 1998 e 2008, com relação à carne Bovina Fresca (SH 0201), segundo os resultados presentes na tabela 4.

TABELA 4 - Índice de Vantagem Comparativa Revelada (IVCR) das exportações brasileiras de Carne Bovina Fresca (SH 0201), Carne Bovina Congelada (SH 0202), Carne Suína (SH 0203), Carne de Frango (SH 0207), Suco de Fruta (SH 1701) e Açúcar Bruto (SH 2009) , 1996-2013201

\begin{tabular}{|c|c|c|c|c|c|c|}
\hline Ano & Carne frango & Carne Suína & $\begin{array}{c}\text { Carne Bovina } \\
\text { fresca }\end{array}$ & $\begin{array}{c}\text { Carne Bovina } \\
\text { Congelada }\end{array}$ & Suco de fruta & Açúcar Bruto \\
\hline \multicolumn{7}{|l|}{1996} \\
\hline 1997 & 9.6428 & 1.2922 & 0.4482 & 4.07 & 21.6027 & 21.2845 \\
\hline 1998 & 8.6412 & 1.0639 & 0.5029 & 7.8014 & 25.3151 & 23.7613 \\
\hline 1999 & 11.3848 & 0.8049 & 1.0905 & 10.9532 & 30.2686 & 20.8811 \\
\hline 2000 & 10.3455 & 1.0157 & 1.7097 & 15.7335 & 18.0569 & 17.1248 \\
\hline 2001 & 14.5035 & 1.8239 & 3.0493 & 26.9199 & 32.8486 & 13.8942 \\
\hline 2002 & 15.598 & 2.683 & 2.5706 & 25.2846 & 31.4133 & 16.119 \\
\hline 2003 & 17.5504 & 2.5412 & 3.1943 & 30.6155 & 29.2787 & 14.8312 \\
\hline 2004 & 18.9831 & 2.5983 & 3.5133 & 50.6264 & 28.5511 & 11.1954 \\
\hline 2005 & 19.6731 & 3.1386 & 2.8679 & 57.6361 & 28.4469 & 9.4507 \\
\hline 2006 & 17.4133 & 2.4457 & 2.5401 & 72.1336 & 36.953 & 10.0033 \\
\hline 2007 & 18.738 & 2.6196 & 2.6848 & 76.5154 & 38.2769 & 12.2754 \\
\hline 2008 & 20.9303 & 2.2179 & 0.7731 & 73.0232 & 33.2181 & 8.7755 \\
\hline 2009 & 18.9298 & 2.023 & 1.0343 & 63.156 & 51.8287 & 8.7941 \\
\hline 2010 & 17.8497 & 1.8993 & 1.2028 & 59.3934 & 62.342 & 8.4156 \\
\hline 2011 & 15.5097 & 1.5044 & 1.1892 & 47.2955 & 57.8982 & 8.0309 \\
\hline 2012 & 15.2009 & 1.59 & 1.6286 & 51.4912 & 45.9556 & 8.0365 \\
\hline 2013 & 15.8041 & 1.4351 & 1.7729 & 67.5553 & 52.394 & 8.39 \\
\hline
\end{tabular}

FONTE: Elaborado pelo autor a partir da base nos dados do UN COMTRADE 
Com relação às importações provenientes da União Europeia, as barreiras não tarifárias ${ }^{4}$ são representadas pelas quotas, subsídios, restrições voluntárias às exportações, ecológicas, técnicas, burocráticas e sanitárias (AZÚA, 1986).

Segundo Viegas (2003), a sanidade animal, sanidade vegetal e as quotas tarifárias são barreiras não tarifárias inseridas sobre as exportações do Brasil. As quotas abarcam bananas, açúcar, carne bovina e carne de frango. O setor de carnes sofre limitação nas suas exportações do Brasil para a União Europeia, tendo em vista a existência de doenças, como febre aftosa (carne bovina), febre suína clássica (carne suína) e doença de Newcastle (carne de frango).

As barreiras técnicas podem ser exemplificadas por meio de rotulagens exigidas, que possuem por atributo ofertar informações sobre a vida do gado bovino. Com relação às exportações de carne bovina do Brasil para a União Europeia, citam-se as regras de controle de segurança alimentar pela Comissão Europeia, intensificadas no ano de 2002, em decorrência do surgimento da doença da vaca louca, acarretando ao Brasil um patamar mais alto de exigência para suas exportações. O surgimento da doença da febre aftosa ocasionou a inclusão de barreiras sanitárias sobre as exportações do Brasil pela União Europeia, proibindo as importações de sêmen de bovinos, bovinos vivos e carne bovina com osso, com relações às regiões do Brasil em que apresentaram a presença da doença da febre aftosa (DOMINGUES, 2008).

Com o objetivo de se medir o potencial de ingresso das exportações do Brasil no mercado europeu, utilizou-se o índice de Orientação Regional (IOR). Esse índice é resultado da divisão entre a fração das exportações, por um dado país (Brasil) para uma referida região (União Europeia), de um produto j (exportação dentro da região) com relação à exportação total para esta mesma região (União Europeia), que é a exportação total intrarregional e a fração das exportações desse mesmo produto para as regiões externas ao bloco europeu com relação às exportações totais para as regiões externas à União Europeia. $O$ valor do IOR é influenciado por fatores que impactam as relações comerciais, como as barreiras comerciais. O índice IOR é representado pela equação 11.

$$
I O R_{k}=\left[X_{k i} I O R_{k}=\left[X_{k i} / X_{t i} X_{t i}\right] /\left[X_{k \theta} / X_{t \theta}\right] X_{k \theta} / X_{t \theta}\right]
$$

Com base na equação $11, X_{k i}$ que é o valor das exportações brasileiras intrabloco $i$ do produto $k$ e $X_{t i}$ o valor total $t$ das exportações brasileiras intrabloco $i$. No denominador, tem-se $X_{k e}$ valor das exportações brasileiras extrabloco e do produto $k$ e $X_{t e}$ é o valor total $t$ das exportações brasileiras extrabloco $e$.

$O$ intervalo em que se encontra o índice é entre zero e o infinito. Um comportamento ascendente para os valores desse índice em um dado período denota a presença de tendência para um patamar crescente de exportações para o mercado regional em voga. Entretanto, no caso em que ocorrer decrescimento desse índice em um dado período de tempo, as exportações estarão canalizadas para fora do bloco. Se os valores do índice estiverem entre zero e um, as exportações terão tendências extrabloco. Existe uma tendência equivalente do país exportador, no caso o Brasil, a exportar os produtos para o bloco, no caso a União Europeia (exportação intrabloco) e exportar para os países não membros da União Europeia (exportação extrabloco).

Com relação aos resultados que constam na tabela 5, com relação à carne Bovina Fresca (SH 0201), o valor do índice IOR teve diminuição no período que engloba os anos de 1997 a 2004 e de 2006 a 2013. Esses resultados permitem evidenciar um nível de exportação mais baixo, o que significa diminuição do potencial exportador. Existe queda do IOR com relação à carne Bovina Congelada (SH 0202) no período que engloba os anos de 1997 a 2005, refletindo em diminuição do potencial exportador, pois, no período entre 2006 a 2013, existe tendência para que ocorra exportação para países não pertencentes ao bloco europeu, sendo que o valor do índice encontra-se entre 0 e 1 . De acordo com as informações da tabela 4, o valor do índice para carne suína (SH 0207), encontrou-se entre 0 e 1 ao longo do período 1996 a 2013, mostrando tendência de exportação extrabloco, o mesmo ocorrendo para a carne de Frango (SH 0207), que exceto para os anos de 2000 a 2003, também apresentaram tendência para a exportação extrabloco. O açúcar bruto apresentou valores crescentes para o índice entre 1996 a 2013, o que evidencia elevação do potencial de exportação do Brasil para a UE.

\footnotetext{
${ }^{4}$ A quota, por se constituir em uma restrição de caráter quantitativo, limita a importação de algumas commodities. O uso de tarifas é o que causa a restrição. Existe a aplicação de uma tarifa mais baixa (intraquota) até o limite da quota e uma tarifa mais alta no caso em que as importações estão acima da quota (extraquota) (KRUGMAN ET AL, 1999). A definição de restrições voluntárias às exportações se refere a uma solicitação do país importador ao país exportador para que ocorra queda nas exportações (KRUGMAN ET AL, 1999). Pagamentos diretos ofertados aos exportadores pertencentes a um país, concessão de isenção fiscal e empréstimos são denominados de subsídios (SALVATORE, 1999). A padronização oriunda de exigência com relação à exigência na inserção de regras sobre consumo, produção alimentar e processamento são as denominadas medidas sanitárias e fitossanitárias (THORSTENSEN, 1999).
} 
TABELA 5 - Índice de Orientação Regional (IOR) das exportações brasileiras de Carne Bovina Fresca (SH 0201), Carne Bovina Congelada (SH 0202), Carne Suína (SH 0203), Carne de Frango (SH 0207), Suco de Fruta (SH 1701) e Açúcar Bruto (SH 2009), Fumo, Soja Grãos (SH 1201), Soja Farelos (SH 2304), Óleo de Soja (SH 1507), Café Grãos (SH 0901), Café Solúvel (SH 2101) 1996-2013

\begin{tabular}{ccccccc}
\hline Ano & $\begin{array}{c}\text { Carne } \\
\text { frango }\end{array}$ & $\begin{array}{c}\text { Carne } \\
\text { Suína }\end{array}$ & $\begin{array}{c}\text { Carne } \\
\text { Bovina } \\
\text { fresca }\end{array}$ & $\begin{array}{c}\text { Carne } \\
\text { Bovina } \\
\text { Congelada }\end{array}$ & $\begin{array}{c}\text { Suco de } \\
\text { fruta }\end{array}$ & $\begin{array}{c}\text { Açúcar } \\
\text { Bruto }\end{array}$ \\
\hline 1996 & & & & & & \\
\hline 1997 & 9.6428 & 1.2922 & 0.4482 & 4.07 & 21.6027 & 21.2845 \\
\hline 1998 & 8.6412 & 1.0639 & 0.5029 & 7.8014 & 25.3151 & 23.7613 \\
\hline 1999 & 11.3848 & 0.8049 & 1.0905 & 10.9532 & 30.2686 & 20.8811 \\
\hline 2000 & 10.3455 & 1.0157 & 1.7097 & 15.7335 & 18.0569 & 17.1248 \\
\hline 2001 & 14.5035 & 1.8239 & 3.0493 & 26.9199 & 32.8486 & 13.8942 \\
\hline 2002 & 15.598 & 2.683 & 2.5706 & 25.2846 & 31.4133 & 16.119 \\
\hline 2003 & 17.5504 & 2.5412 & 3.1943 & 30.6155 & 29.2787 & 14.8312 \\
\hline 2004 & 18.9831 & 2.5983 & 3.5133 & 50.6264 & 28.5511 & 11.1954 \\
\hline 2005 & 19.6731 & 3.1386 & 2.8679 & 57.6361 & 28.4469 & 9.4507 \\
\hline 2006 & 17.4133 & 2.4457 & 2.5401 & 72.1336 & 36.953 & 10.0033 \\
\hline 2007 & 18.738 & 2.6196 & 2.6848 & 76.5154 & 38.2769 & 12.2754 \\
\hline 2008 & 20.9303 & 2.2179 & 0.7731 & 73.0232 & 33.2181 & 8.7755 \\
\hline 2009 & 18.9298 & 2.023 & 1.0343 & 63.156 & 51.8287 & 8.7941 \\
\hline 2010 & 17.8497 & 1.8993 & 1.2028 & 59.3934 & 62.342 & 8.4156 \\
\hline 2011 & 15.5097 & 1.5044 & 1.1892 & 47.2955 & 57.8982 & 8.0309 \\
\hline 2012 & 15.2009 & 1.59 & 1.6286 & 51.4912 & 45.9556 & 8.0365 \\
\hline 2013 & 15.8041 & 1.4351 & 1.7729 & 67.5553 & 52.394 & 8.39 \\
\hline
\end{tabular}

FONTE: Elaborado pelo autor a partir da base nos dados do UN COMTRADE

\section{RESULTADOS}

Para os produtos carne bovina fresca, carne bovina congelada, carne suína, carne de frango, suco de laranja e açúcar-bruto, apresenta-se os resultados do Índice de Introversão ao Comércio e do índice simétrico de propensão relativa ao comércio intrarregional nas figuras 4 a 15 . Todas as figuras apresentam o resultado do índice de introversão ao comércio próximo a um, mostrando que, nesses produtos selecionados, há a presença quase total de desvio de comércio no período de 1996 a 2013, corroborados pelas Figuras que mostram os resultados do índice de propensão relativa ao comércio, com valores próximos a um, exceto, para o sistema harmonizado 0202, que são as carnes bovinas congeladas, que mostram valores crescentes a partir de 1996, chegando próximo a 1 no ano de 2005.

Os valores do índice de introversão ao comércio encontram-se na figura 4, sendo que o mesmo é praticamente igual a um, o que denota quase presença plena de desvio de comércio com relação aos países que não são membro deste bloco, o que significa que existe plena criação de comércio intrabloco.

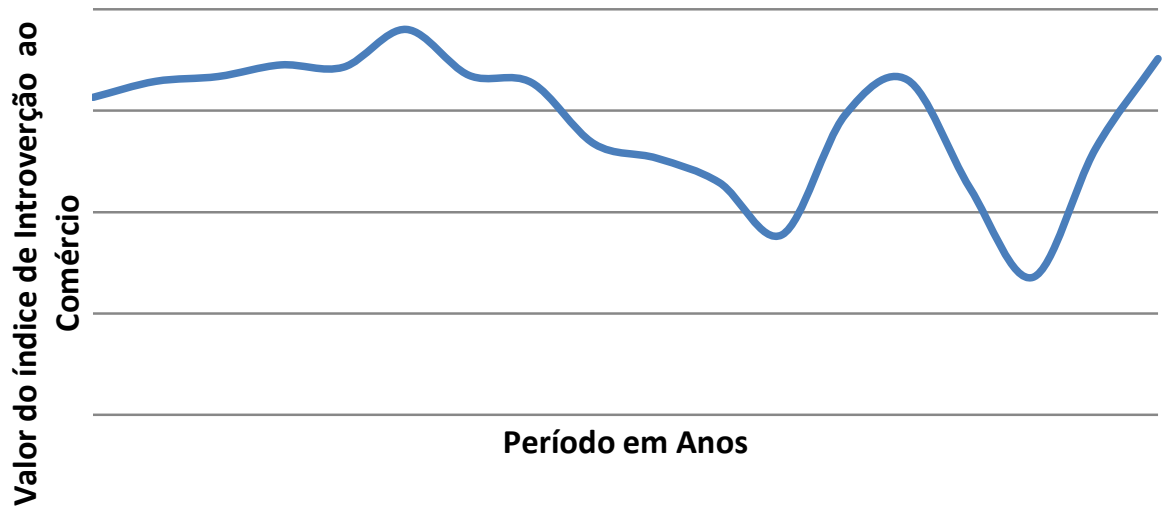

FIGURA 4 - Índice de Introversão ao Comércio para carne bovina fresca (SH 0201) FONTE: UN Comtrade (Tabulado pelo autor) 
O resultado do índice de propensão relativa ao comércio mostra valores acima de 0,9 para todo o período entre os anos de 1996 a 2013, conforme a figura 5. Mesmo com as oscilações, praticamente, existe apenas desvio de comércio extrabloco na comercialização desse produto, haja vista que o efeito preponderante do efeito de desvio de comércio com relação ao efeito de criação de comércio de acordo com o valor desse índice, que está próximo de um o que denota efeito de criação de comércio intrabloco . As informações da Figura 5 corroboram com as da Figura 4, mostrando que o comércio intrarregional é muito maior do que o comércio extrarregional, evidenciando que há pouco acesso das exportações de carne bovina fresca ao mercado europeu.

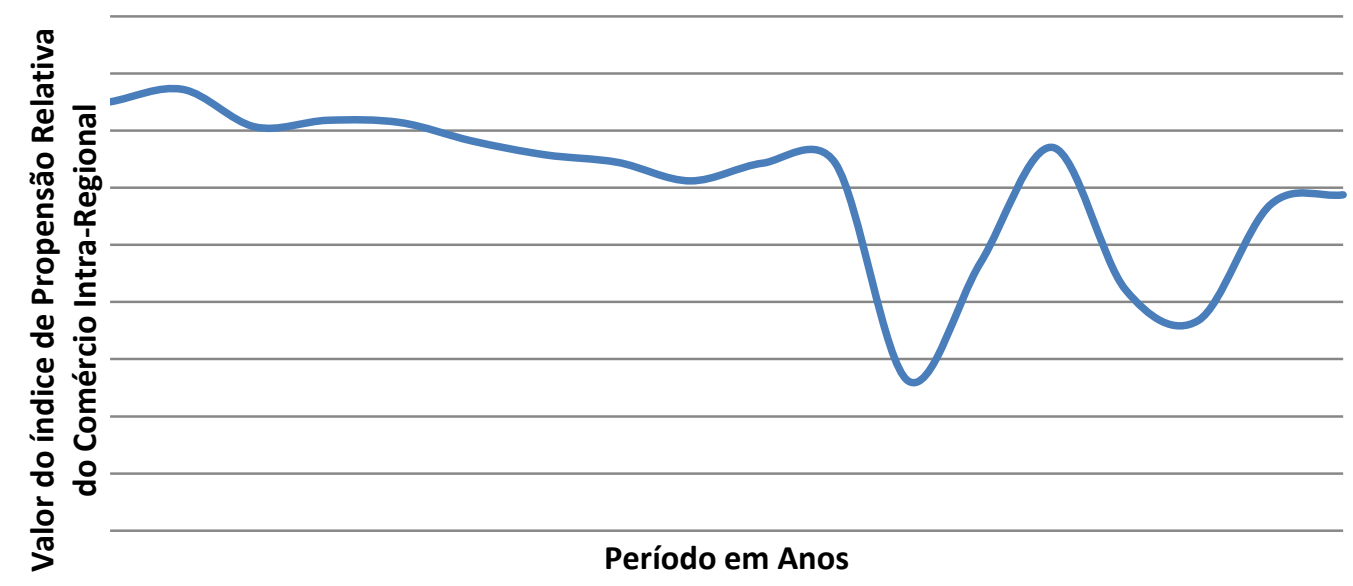

FIGURA 5 - Propensão Relativa do Comércio Intrarregional para carne bovina fresca (SH 0201) FONTE: UN Comtrade (Tabulado pelo autor)

Por meio das informações da figura 6, nota-se que o índice de introversão ao comércio apresenta um comportamento ascendente, de um patamar de 0,4 para um valor próximo a um no ano de 2013. Assim sendo, esse setor mostra a presença quase total de desvio de comércio (com relação aos países não pertencentes à União Europeia) e quase ausência de criação de comércio das importações do bloco europeu, principalmente, para os anos mais recentes. Sob a ótica do mercado interno do bloco europeu, esse resultado denota que a comercialização desse produto internamente sofreu aumento a partir de 1996, tendo por base a série do índice de introversão ao comércio, ficando restrito praticamente no mercado interno de 2005 a 2013.

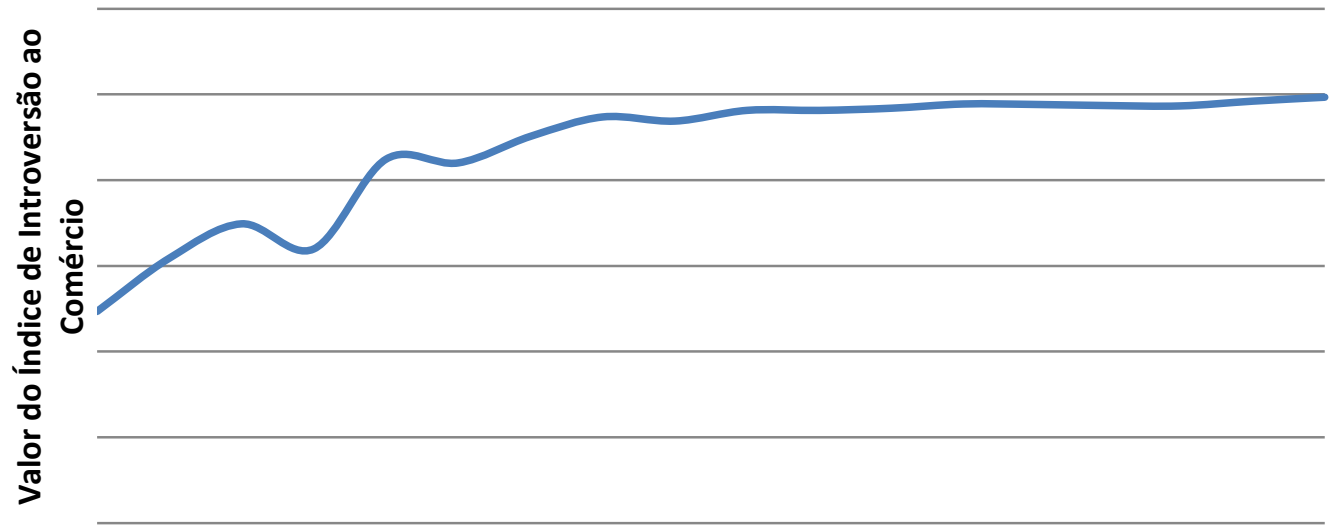

Período em Anos

FIGURA 6 - Índice de Introversão Comercial para carne bovina congelada (SH 0202)

FONTE: UN Comtrade (Tabulado pelo autor) 
Com relação aos valores do índice de Propensão Relativa do Comércio Intrarregional, conforme a figura 7, observa-se um comportamento crescente de 1996 a 2013, mostrando que o efeito de desvio de comércio da União Europeia com relação aos seus parceiros comerciais foi aumentando no referido período de estudo, o que denota aumento do efeito de criação de comércio intrabloco, o que reforça os resultados oriundos do índice de introversão ao comércio. Em 2013, com valor de 0,9, nota-se a presença quase total do efeito de desvio de comércio em detrimento do efeito de criação de comércio. As informações da figura 7 corroboram aquelas presentes na figura 6 , que apresentou o mesmo comportamento de valores ascendentes de 1996 a 2013, mostrando um efeito cada vez maior do desvio de comércio frente ao efeito de criação de comércio da UE com relação aos seus parceiros comerciais selecionados neste trabalho.

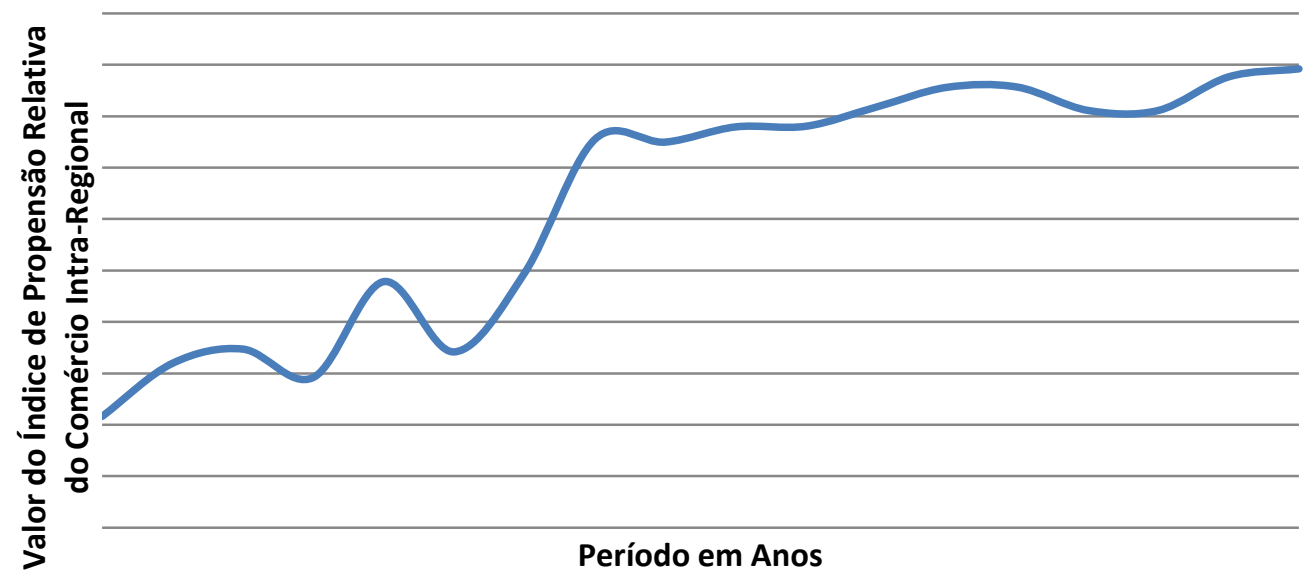

FIGURA 7 - Propensão Relativa do Comércio Intrarregional para carne bovina congelada (SH 0202) FONTE: UN Comtrade (Tabulado pelo autor)

As informações com relação aos valores do índice de introversão, presentes na Figura 8, permitem observar um comportamento estável ao longo do período de 1996-2013, com valor um no ano de 1997 e para os demais anos, valores bem próximos de um, o que denota concentração do comércio dentro do mercado europeu, ou seja, um efeito de criação de comércio intrabloco.

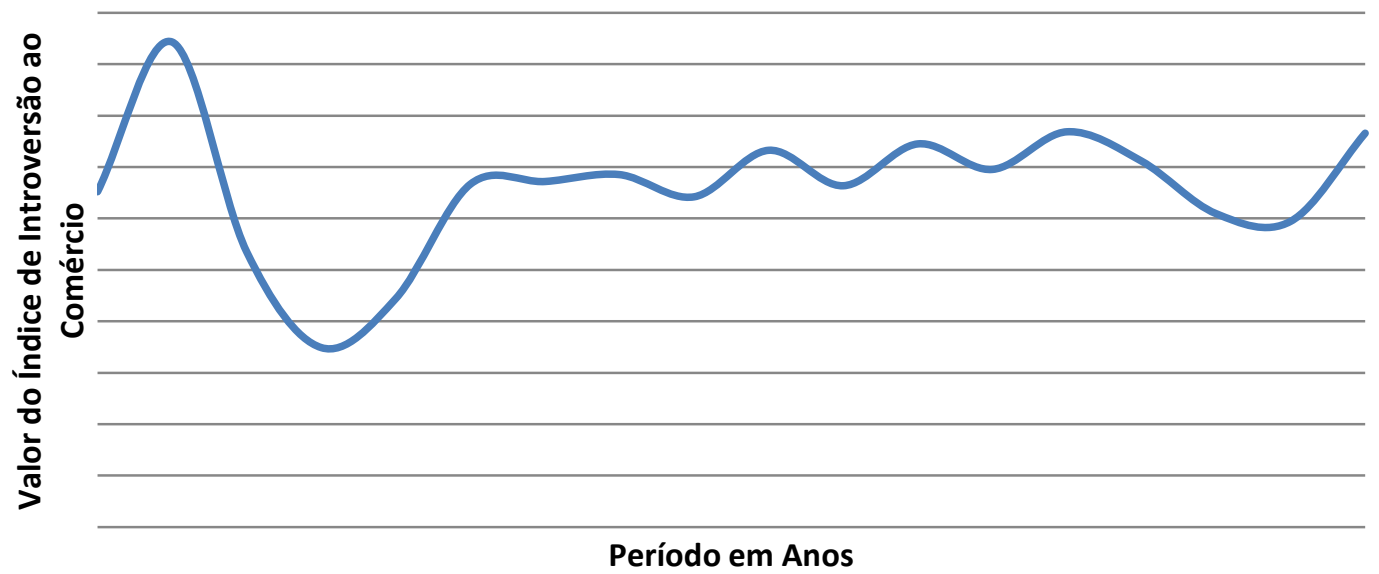

FIGURA 8 - Índice de Introversão ao Comércio para a carne suína (SH 0203)

FONTE: UN Comtrade (Tabulado pelo autor)

Os valores do índice de propensão relativa ao comércio intrarregional apresentam um comportamento oscilatório, conforme as informações da figura 9, com um valor mínimode 0,84 no ano de 1999 e um pico acima de 0,94 no ano de 1997. No ano de 2013, o índice foi um pouco superior a 0,92. Em todo caso, 
quanto mais próximo de um, maior é o efeito do desvio de comércio extrabloco sobre o de criação de comércio. Portanto, com relação aos valores apresentados na Figura 9, fica evidente que o efeito de desvio de comércio é bem superior ao efeito de criação de comércio.

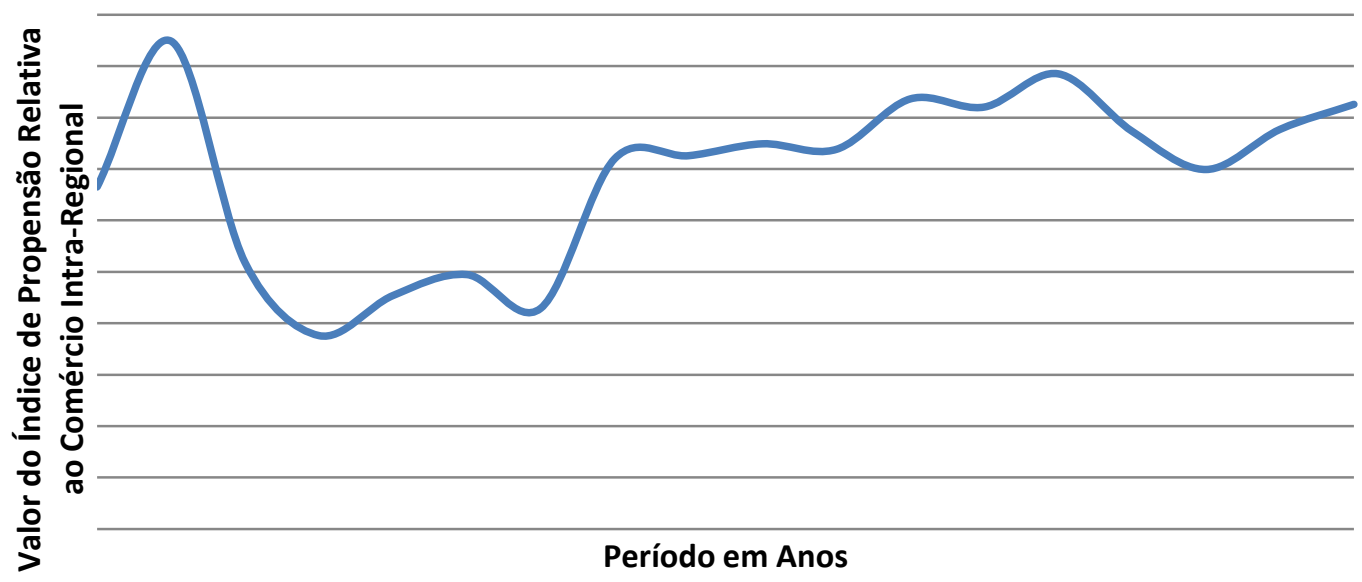

FIGURA 9 - Propensão Relativa do Comércio Intrarregional para carne suína (SH 0203) FONTE: UN Comtrade (Tabulado pelo autor)

Observa-se, de acordo com as informações da figura 10, um comportamento estável da série dos resultados do índice de introversão ao comércio, com valor acima de 0,9 a partir de 1999 e, para os demais anos, valores próximos de um a partir de 2007. Isso significa que a comercialização desse produto fica restrita no interior do bloco no que se refere à carne de Frango.

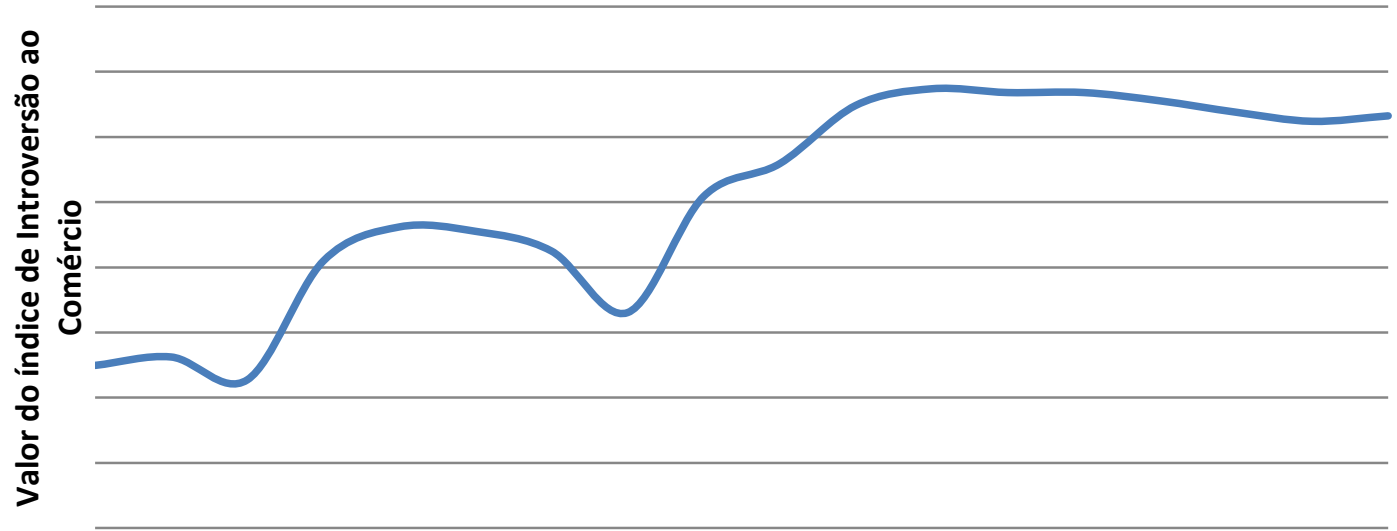

Período em Anos

FIGURA 10 - İndice de Introversão ao Comércio para carne de Frango (SH 0207) FONTE: UN Comtrade (Tabulado pelo autor)

Os valores do índice de Propensão Relativa do Comércio Intrarregional para carne de frango no mercado europeu refletem os resultados da Figura 11, o que mostra que o efeito do desvio de comércio é muito superior ao efeito de criação de comércio, o que reflete um mercado estritamente fechado para as exportações dos países não pertencente a este bloco econômico. 


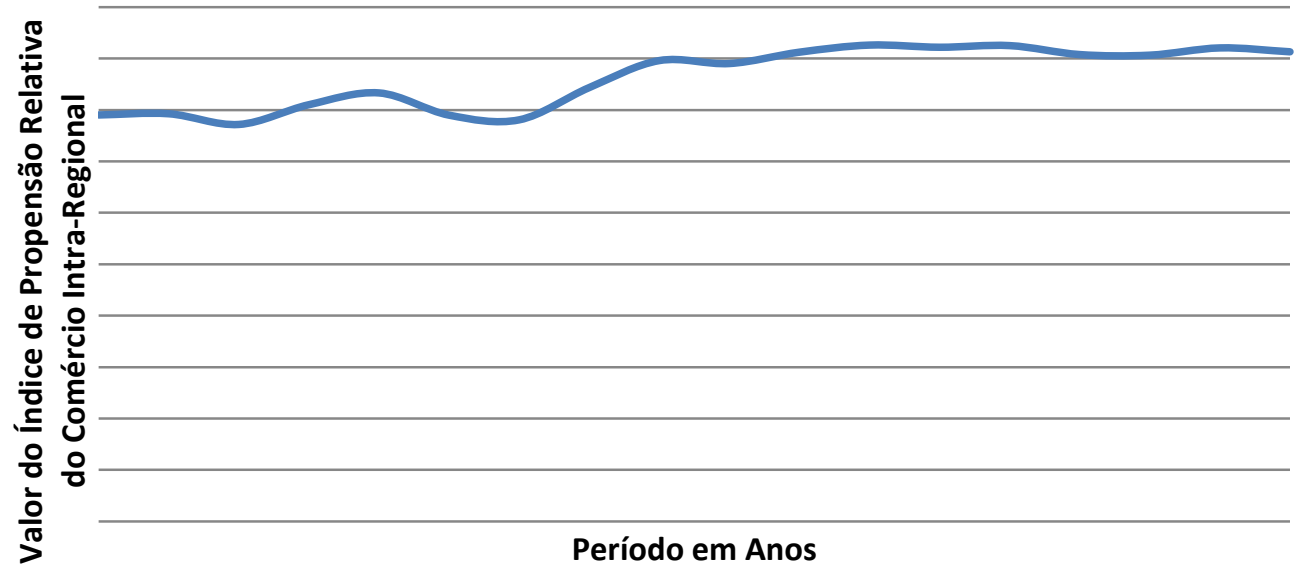

FIGURA 11 - Propensão Relativa do Comércio Intrarregional para carne de Frango (SH 0207) FONTE: UN Comtrade (Tabulado pelo autor)

Para o setor do açúcar bruto, segundo os dados da figura 12, os valores do índice de introversão crescem a partir do ano de 1998, o que mostra aumento do protecionismo do bloco europeu frente às exportações dos seus parceiros comerciais. De 2007 a 2013, o índice se encontra próximo de um, o que denota a presença quase plena de desvio de comércio extrabloco e ausência quase total do efeito de criação de comércio, o que reflete um efeito de criação de comércio intrabloco.

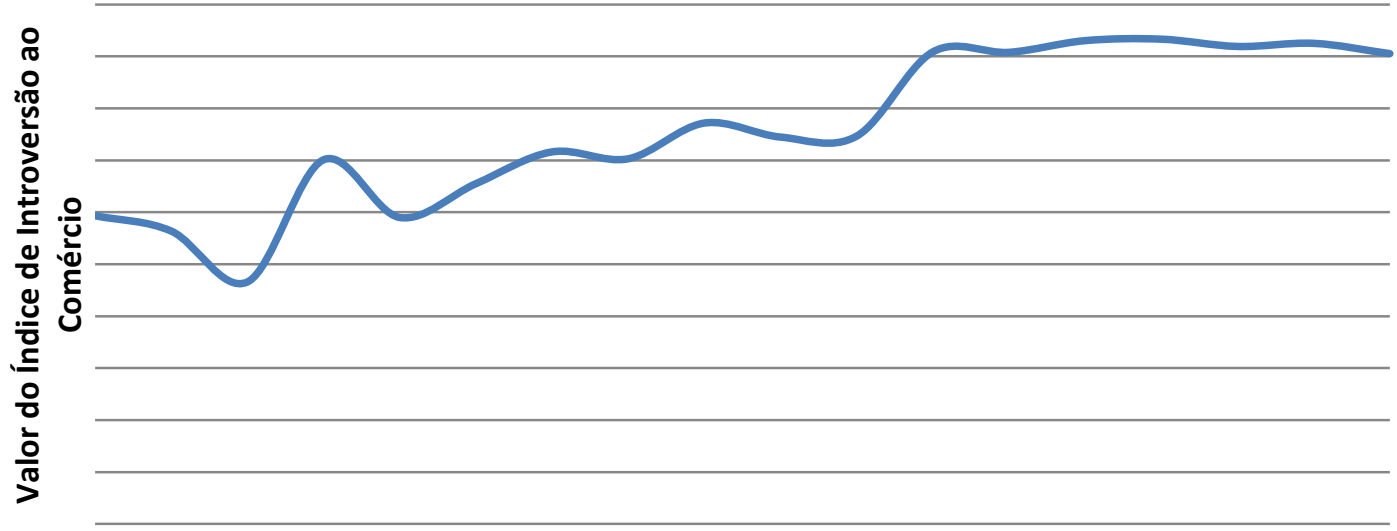

Período em anos

FIGURA 12 - Índice de Introversão ao Comércio para Açúcar Bruto (SH 1701)

FONTE: UN Comtrade (Tabulado pelo autor)

De acordo com os resultados do índice de propensão relativa ao comércio, na Figura 13, observa-se que o desvio de comércio é preponderante sobre o efeito de criação de comércio, dado que à medida que 0 índice se aproxima de um, o efeito de criação de comércio diminuiu e o efeito de desvio de comércio extrabloco se eleva. 


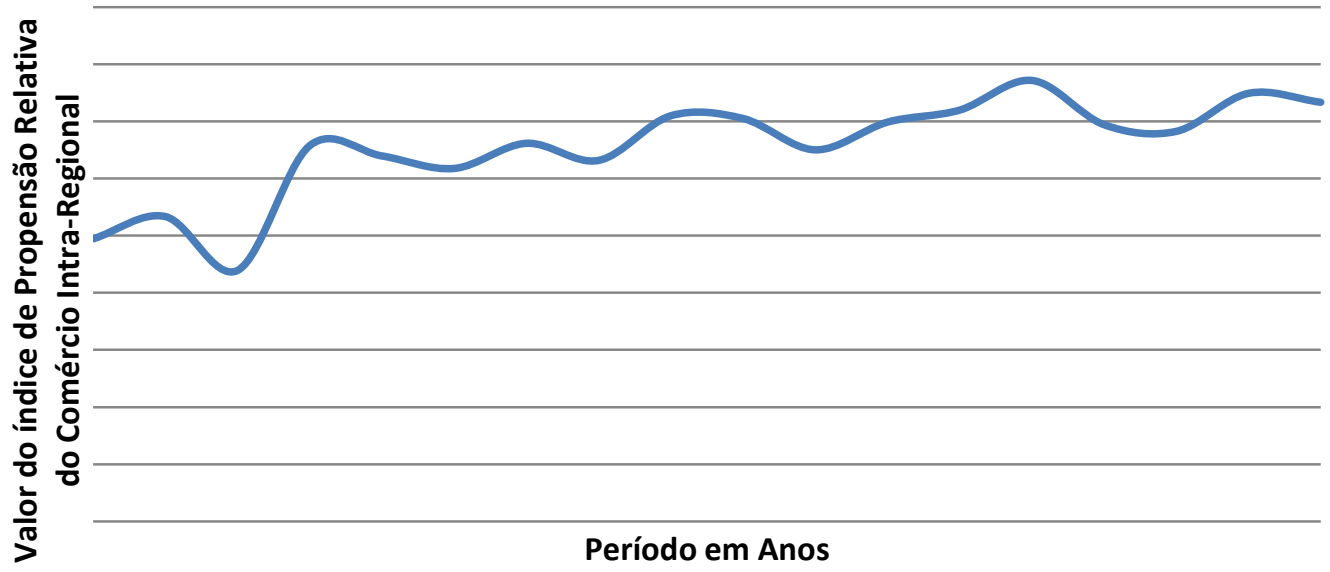

FIGURA 13 - Propensão Relativa do Comércio Intrarregional para Açúcar Bruto (SH 1701) FONTE: UN Comtrade (Tabulado pelo autor)

Observa-se que o índice de introversão apresenta comportamento ascendente a partir de 1999, após um período de queda do ano de 1996 a 1999, ficando próximo de 0,7, o que significa um efeito de desvio de comércio acima do efeito criação de comércio da UE frente aos seus parceiros comerciais, o que significa um grande efeito de criação de comércio dentro do bloco econômico, conforme os resultados que constam na figura 14.

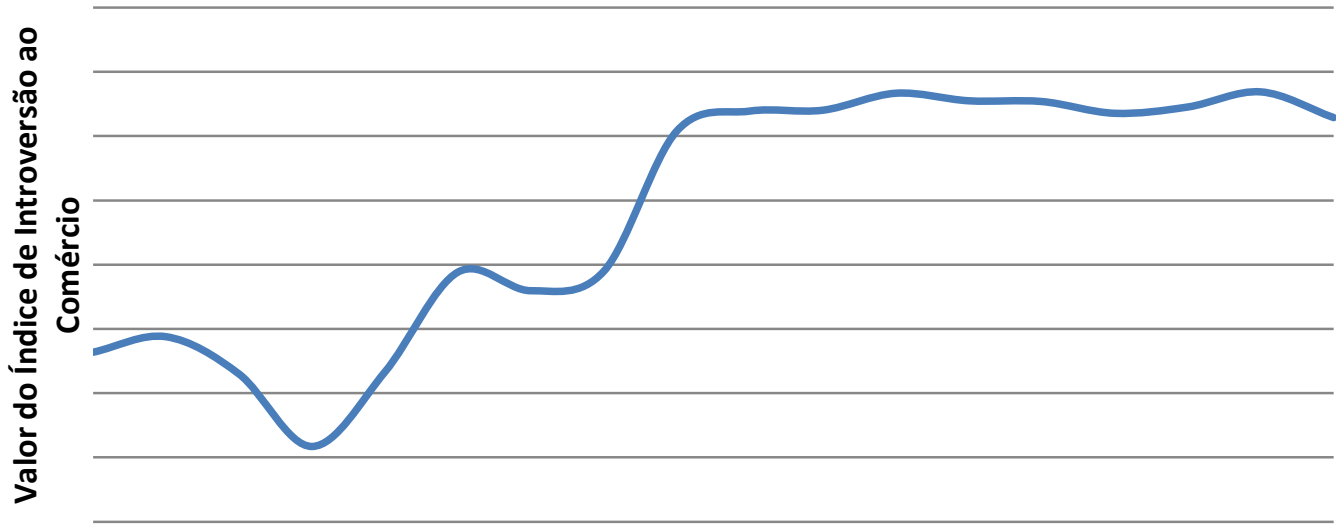

\section{Período em Anos}

FIGURA 14 - Índice de Introversão ao Comércio para Suco de Laranja Concentrado (SH 2009) FONTE: UN Comtrade (Tabulado pelo autor)

É possível observar por intermédio das informações da figura 15 que o efeito de desvio de comércio acima do efeito de criação de comércio, mostrando que o mercado europeu é protecionista frente às exportações dos seus parceiros comerciais para o suco de laranja concentrado. 


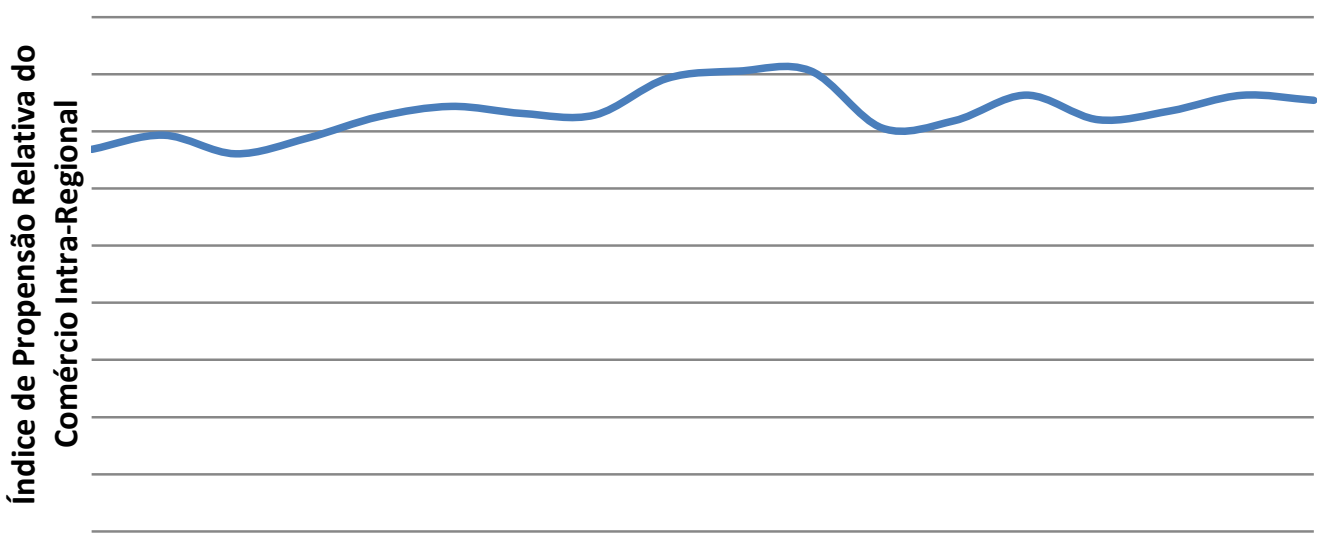

Período em Anos

FIGURA 15 - Propensão Relativa do Comércio Intrarregional para Suco de Laranja Concentrado (SH 2009) FONTE: UN Comtrade (Tabulado pelo autor)

\section{CONCLUSÃO}

As políticas da União Europeia com relação ao mercado dos produtos agroindustriais são de caráter intervencionista. A PAC é o órgão responsável por esse intervencionismo, permitindo que os produtos agroindustriais produzidos pelos países da União Europeia circulem livremente dentro da União Europeia em virtude da completa erradicação das barreiras comerciais entre os países membros do bloco europeu. Com relação ao comércio do bloco europeu com seus parceiros comerciais, há a incidência de barreiras tarifárias, destacando-se os picos tarifários, que, segundo a definição da $\mathrm{FAO}$, são tarifas com patamares acima de $20 \%$ e também de barreiras não tarifárias, que são representadas por medidas sanitárias, fitossanitárias e barreiras técnicas, que a priori são padronizações de regras que possuem por objetivo atender a algumas exigências sobre o consumo, produção e processamento, mas que também podem ser empregadas com o fito de proteger o mercado europeu da concorrência estrangeira. Outras barreiras não tarifárias empregadas pelo bloco europeu são as burocráticas, ecológicas, subsídios, e quotas.

O baixo nível de competitividade do bloco europeu se comparado, por exemplo, ao Brasil, é a razão pela qual há a inserção as barreiras tarifárias e não tarifárias. Com relação ao nível de competitividade, os resultados do Índice de Vantagem Comparativa Revelada (IVCR) mostram que o Brasil detém vantagem comparativa com relação à União Europeia para carne bovina Fresca (SH 0201), carne bovina congelada (SH 0202), carne suína (SH 0203), carne de frango (SH 0207), suco de fruta (SH 1701), açúcar bruto (SH 2009).

O Brasil ganharia por meio do aumento das elevações das suas exportações caso o bloco europeu reduzisse suas barreiras tarifárias e não tarifárias, conforme os resultados do índice de Orientação Regional (IOR), cujos resultados mostram uma queda do potencial exportador do Brasil de carne bovina fresca (SH 0201), carne bovina congelada (SH 0202) e tendência de exportação extrabloco (exportações para localidades fora da União Europeia) para carne suína (SH 0203), carne de frango (SH 0207), o que denota uma grande dificuldade de ingresso das exportações do Brasil no mercado europeu para esses produtos mencionados.

Para efeito de análise, selecionaram-se aqueles produtos que recebem tarifas superiores a $20 \%$, os denominados picos tarifários, para um período que engloba os anos de 1996 a 2013, período escolhido tendo por base as observações de Freitas et al. (2007), que constatou a presença do protecionismo europeu a partir de 1995, ano em que ocorreu a consolidação da UE-15, portando, nota-se que o bloco europeu já estava adotando medidas protecionistas antes do ano de $2004^{5}$, ano em que ocorreu o ingresso dos países do leste europeu na União Europeia.

Os produtos selecionados para a análise, por intermédio dos Índices de Introversão ao Comércio e Índice de Propensão Relativa do Comércio Intra-Regional, foram a carne bovina fresca (SH 0201), carne bovina congelada (SH 0202), carne suína (SH 0203), carne de frango ( $\mathrm{SH} 0207)$, suco de fruta (SH 1701) e Açúcar Bruto (SH 2009). Os resultados dos índices mostram que a União Europeia concentra suas relações comerciais dentro do bloco em detrimento dos seus parceiros comerciais, em que o índice de Propensão

\footnotetext{
${ }^{5} \mathrm{O}$ ano de 2004 é caracterizado pelo ingresso dos países do leste europeu na União Europeia.
} 
Relativa do Comércio Intrarregional mostra um efeito preponderante do efeito de desvio de comércio frente ao efeito de criação de comércio da União Europeia no que diz respeito às suas importações provenientes dos 48 parceiros comerciais, sobretudo, para carne bovina fresca ( $\mathrm{SH}$ 0201), para todo o período de análise, carne bovina congelada (SH 0202), para o período a partir do ano de 2003, carne suína (SH 0203) e carne de frango (SH 0207), em que o valor desse índice é superior a 0,8. Os resultados do índice de Propensão Relativa do Comércio Intrarregional são corroborados pelos resultados dos índices de introversão ao comércio, que mostram a presença quase total de comércio intrabloco (efeito de criação de comércio intrabloco), o que denota a concentração do comércio dos países europeus dentro do mercado da UE em detrimento dos seus parceiros comerciais não pertencentes a esse bloco econômico, incluindo-se o Brasil, para a carne bovina fresca (SH 0201) para o período de 1996 a 2013, carne bovina congelada (SH 0202) a partir do ano de 2003, carne suína (SH 0203) e carne de frango (SH 0207), mostrando que há dificuldades de ingresso das exportações. Isso é fruto das aplicações das barreiras tarifárias e não tarifárias pela União Europeia sobre suas importações.

Os resultados do índice de Orientação Regional (IOR) e a dos indicadores de lapadre (2004) possibilitam afirmar que o mercado europeu é fechado para as importações dos produtos selecionados neste estudo. É fácil observar que o fato de o destino dos produtos selecionados serem extrabloco, ou seja, para outras regiões que não a UE e também a queda do potencial exportador. Os resultados do IOR estão atrelados ao baixo grau de abertura comercial, resultado do efeito de desvio de comércio, captado pelo Índice de Propensão Relativa do Comércio Intrarregional, decorrência da concentração do comércio desses produtos entre os países membros da União Europeia, conforme os resultados do Índice de Introversão ao Comércio.

A vantagem do emprego dos indicadores de lapadre para o estudo da temática deste artigo se deve ao fato de que, nas estimações do modelo gravitacional, há uma grande oscilação na intensidade do comércio bilateral em virtude do surgimento de ligações preferenciais, como a concretização de um acordo de livre comércio, fluxo migratório, uso de uma língua comum, bem como do tamanho relativo dos parceiros e da distância entre eles e também de um conjunto de fatores adicionais, como regulamentos, diferentes moedas, restrições quantitativas e tarifas, ao passo que esses índices empregados à evolução comercial de blocos e países de forma perfeita, de acordo com lapadre et al. (2010). Outros pontos positivos, segundo Domingues (2008), são a facilidade em calculá-los, custos reduzidos, além de serem facilmente compreendidos e possuírem alguma importância estatística.

Contudo, os indicadores aplicados neste trabalho não possuem robustez e coerência no que tange à teoria econômica e nem um grande poder de explicação se comparado com os modelos gravitacionais. $O$ índice de Introversão ao Comércio e o índice de Propensão Relativa do Comércio Intrarregional não incorporaram os pressupostos da teoria da economia internacional por não inserir outras variáveis relacionadas a essa teoria, como a distância entre dois países, dummies de língua comum, fronteira comum, dados relacionados à aplicação de tarifas, dummies relacionadas a barreiras não tarifárias, dummies que capturam efeitos de criação e desvio de comércio extrabloco e intrabloco, além de não mensurarem os efeitos exercidos pela concretização de um bloco econômico sobre o bem-estar, o que os tornam mais limitados em virtude do menor poder de explicação se comparado com o modelo gravitacional. Assim, para que se obtenham resultados mais robustos, consistentes e completos com relação à estimação de efeitos de criação ou desvio de comércio das importações europeias de produtos que recebem a incidência dos picos tarifários, faz-se necessário aplicar o modelo gravitacional, por meio do uso dos métodos de efeito fixo-MQO, PPML (Pseudo Poisson Maximum Likelihood), que controlam tendenciosidade, que é resultado da heterogeneidade entre pares de países nas relações comerciais e Heckman que trabalha com a presença de fluxo comercial bilateral zero na equação estimada.

\section{REFERÊNCIAS}

ADAMS, R.; D. E. E., P.; GALI, J.; MCGUIRE, G. The Trade and Investment Effects of Preferential Trading Arrangements-Old and New Evidence. Canberra: Productivity Commission Staff Working Paper, 2003. Disponível em: <http://www.pc.gov.au/research/completed/preferential-trade-agreements >. Acesso em: 20 set. 2015.

ANDERSON, V. Alternative Economic Indicators. Routledge, London, 1991.

AZÚA, D. E. R. O neoprotecionismo e o comércio exterior. São Paulo: Aduaneiras, 1986. 340 p.

BALASSA, B. Trade Liberalisationand "Revealed" Comparative Advantage. Manchester School of Economic and Social Studies, Manchester, n. 2, v. 33, p. 99-123, May, 1965.

BALDWIN, R. E.; VENABLES, A. J. Regional Economic Integration. In: Gene Grossman; Kenneth Rogoff (eds.). Hand book of International Economics, Amsterdam: North-Holland, 1995. chap. 31, p. 1597-1644.

CONFEDERAÇÃO NACIONAL DA AGRICULTURA-CNA. Informativo. Disponível em: <http://www.canaldoprodutor.com.br/sites/default/files/informativo-uniaoeuropeia-edicaoespecial3.pdf>. Acesso em: 10 Jan. 2015. 
DOMINGUES, G, C. Fluxos de Comércio no Mercosul: Índices de Mensuração Comercial 1995-2005. 2008. 69 p. Dissertação (Mestrado em Economia) - Universidade de Brasília, Brasília, 2008.

DOMINGUES, M. A. As principais barreiras pautais e não pautais impostas à importação da carne bovina brasileira pela comunidade europeia. Revista Jurídica da Unifil, Londrina, v. 5, n. 5, p. 96-112, out./dez. 2008.

DOMINGUES, G, C. Fluxos de Comércio no Mercosul: Índices de Mensuração Comercial 1995-2005. 2008. 80 p. Dissertação (Mestrado em Economia)-Universidade de Brasília, Brasília, 2008.

FRANKEL, J, A. Regional trading blocs in the world economic system, Institute for International Economics, Washington, 1997.

FREITAS, R. E.; COSTA, C. Cabral da. Tarifas agrícolas Europeias: mensuração e análise entre produtos. Estudo Econômico, São Paulo, v. 37, n. 1, p. 167-209, jan./mar. 2007.

FREITAS, R. E. Barreiras Comerciais sobre os Produtos Agrícolas Brasileiros na União Europeia. 2004. 155p.

Tese (Doutorado em Economia) - Escola Superior de Agricultura "Luiz de Queiroz", Universidade de São Paulo, Piracicaba, 2004

GONÇALVES, R. Estratégias de desenvolvimento e integração da América do Sul: divergência e retrocesso. Revista da Sociedade Brasileira de Economia Política, Rio de Janeiro, n. 25, p. 32-51, dez, 2009.

IAPADRE, L. Regional Integration Agreements and the Geography of World Trade: Statistical Indicators and Empirical Evidence. Second Annual Conference of the Euro-Latin Study Network on Integration and Trade. Anlnitiative of the Inter-American Development Bank, out, 2004.

IAPADRE, L.; FRANCESCA, L. Trade Regional is at ion and Openness in Africa. European Report on Development. EUI Working Paper RSCAS 2010/54. European University Institute, Florence, 2010.

KRUGMAN, P.; OBSTFELD, M. Economia Internacional: teoria e política. São Paulo: Makron Books, 1999. 742 p.

KUNIMOTO, K. Typology of Trade Intensity Indices. Hitotsubashi Journal of Economics, v. 17, p. 15-32, 1977.

PANAGARIYA, A. Preferential Trade Liberalization: The Traditional Theory and New Developments. Journal of Economic Literature, v. 38,n. 2, p. 287-331, 2000.

PETRI, P. A. The East Asian Trading Bloc: An Analytical History. In: Frankel, J.; Kahler, M (ed.). Regionalism and Rivalry: Japan and the United States in Pacific Asia. Chicago: University of Chicago Press, 1993. chap. 1, p. 21-52.

PLUMMER, M, G.; CHEONG, D.; HAMANAKA, S. Methodology for Impact Assessment of Free Trade Agreements. Manila: Asian Development Bank, 2010. 108 p.

SALVATORE, D. Economia Internacional. Rio de Janeiro: Livros Técnicos Científicos (LTC), 1999. 326p.

THORSTENSEN, V. Organização Mundial do Comércio: as regras do comércio internacional e a rodada do milênio. São Paulo: Edições Aduaneiras, 1999. 517 p.

UNITED NATIONS COMMODITY TRADE STATISTICS DATABASE-COMTRADE. Disponível em:

<http://comtrade.un.org/db>. Acesso em: 23 jul. 2014.

VIEGAS, I.F.P. Impactos das Barreiras Comerciais dos Estados Unidos e União Europeia sobre a Pauta de Exportações Agrícolas Brasileiras. 2003. 68 p. Dissertação (Mestrado em Economia) - Escola Superior de Agricultura "Luiz de Queiroz", Universidade de São Paulo, Piracicaba, 2003.

VIEGAS, I.F.P. Impactos das Barreiras Comerciais dos Estados Unidos e União Europeia sobre a Pauta de Exportações Agrícolas Brasileiras. 2003. 68 p. Dissertação (Mestrado em Economia) - Escola Superior de Agricultura "Luiz de Queiroz", Universidade de São Paulo, Piracicaba, 2003.

WORLD INTEGRATED TRADE SOLUTION-WITS. Disponível em: <http://wits.worldbank.org/>.Acesso em: 5 jan. 2015.

YEATS, A. Does Mercosur's trade performance raice concerns about the effects of regional trade arrangements? Washington: Policy Research Working Paper, 1997, 33 p (Policy Research Working Paper, 1729). 
